\title{
Auditor-Client Interactions in the Changed UK Regulatory Environment - A Revised Grounded Theory Model
}

\begin{abstract}
Audit and financial reporting quality are under intense scrutiny nationally and globally. The outcome of high-level auditor-auditee discussion and negotiation issues (auditorclient interactions) is central to this debate. Beattie et al. (2001) developed a grounded theory model of these interactions in the 1997 UK setting. This paper reports on a field study of 45 interactions in nine case companies in the radically changed post-SOX regulatory environment. Crucially, interviewees in each case company extend the chief financial officer - audit partner dyad to include the audit committee chair. Fundamental revisions to the model emerge. The strongest influence on interactions has become the national enforcement regime, overlaid upon the international standard-setting regime. The outcome in both the eyes of the participants and in our evaluation is full compliance (contrary to the findings from the 1997 setting), regardless of the perceived quality of the standards and the integrity of the outcome. Personal and company characteristics, which were of most importance in 1997, have become peripheral. The audit committee chair is shown to fulfil a gatekeeping role in relation to the full audit committee.
\end{abstract}

Keywords: auditor-client interaction; audit committee; audit committee chair; discussion; enforcement; financial reporting quality; IFRS; ISAs; negotiation. 


\section{Auditor-Client Interactions in the Changed UK Regulatory Environment - A Revised Grounded Theory Model}

\section{INTRODUCTION}

The global financial crisis has served to heighten concern regarding the performance of auditors and the quality of financial reporting generally (e.g. EC, 2011; House of Lords, 2011, 2012). One key issue being debated is the need to establish a principles-based disclosure framework (EFRAG/ANC/FRC, 2012; IASB, 2013a; IIRC, 2013) to eliminate irrelevant disclosures and better organise disclosure. Another key debate concerns measures to enhance audit quality, including further extending the role of the audit committee (Competition Commission, 2013). Additionally, the inherent quality of IFRS as a set of accounting standards is now being questioned in public discourse surrounding the banking crisis (Beattie et al., 2008a; House of Lords / House of Commons, 2013). (To aid the reader, a full list of abbreviations used in the paper is provided in Appendix 1 and key terms are defined in Appendix 2.)

Behavioural models of auditor-client interactions ${ }^{1}$, covering antecedents and consequences, have been developed and tested using both inductive and deductive approaches using a range of experimental, questionnaire and interview methods in several settings (principally the US, Canada and the UK). For a recent review focussing on deductive approaches see Salterio (2012). ${ }^{2}$ The seminal qualitative study by Beattie, Fearnley \& Brandt (2001) (hereafter BFB) was reported in a research book titled Behind Closed Doors: What Company Audit is Really About. ${ }^{3}$ A grounded theory model of the negotiation process was developed and findings were summarised in a paper in the International Journal of Auditing (Beattie et al., 2004). This study contributed towards establishing audit negotiation and interaction as a clearly identifiable research area (Salterio, 2012, p. 235).

In the decade following the collection of data for the original study, several radical changes occurred in the UK accounting, audit and governance environment. First, the mandatory adoption of International Financial Reporting Standards (IFRS) for the group accounts of all EU listed companies from 2005 resulted in a more technically complex accounting regime for listed companies. Second, the Auditing Practices Board was given responsibility for setting ethical standards for auditors and adopted International 
Standards on Auditing (ISAs) amended for use in the UK (APB, 2004a) for 2005 year ends. These are based on ISAs set by the International Auditing and Assurance Standards Board (IAASB) and include ISA 260 (APB, 2004b) which requires the auditor to engage with the client's audit committee on audit and accounting related matters. Third, changes to the UK Corporate Governance Code (previously known as the Combined Code for Corporate Governance) ${ }^{4}$ required audit committees to engage with the audit and financial reporting process in a more formalised way. Under the comply or explain regime, if this requirement was not complied with, the company had to offer an explanation. Finally, in terms of enforcement, the Financial Reporting Review Panel $(\text { FRRP })^{5}$, the UK's financial reporting enforcement body, was given a new pro-active remit and a new body, the Audit Inspection Unit (AIU), was set up under the aegis of an expanded and reformed Financial Reporting Council (FRC), to inspect public interest audits and issue public reports on their findings. ${ }^{6}$ In summary, key changes likely to influence financial reporting and audit quality since Behind Closed Doors was published were the move to more rules-based and complex set of accounting standards (relative to UK GAAP), the enhanced engagement of the company's audit committee and stronger monitoring of both audit quality and overall financial reporting quality.

The impact of these changes on the behaviour of preparers and auditors was investigated in a follow-up field study by Beattie, Fearnley \& Hines (2011). The parties interviewed included, for the first time, the audit committee chair (ACC) along with the audit engagement partner (AP) and the chief financial officer (CFO). This study therefore responded to Nelson and Tan's (2005) call for research that recognises that practice has changed 'to involve audit committees and various forms of regulatory oversight to a greater extent'. The research question is unchanged from the original field study and can be stated as follows: How do companies and their auditors resolve important financial reporting issues?

Matched interviews were conducted with the CFOs, APs and ACCs of nine major UK listed companies who had recently engaged in significant discussions and negotiations. Interviewees were asked to 'tell the story' of these interactions. The analytical procedures followed enable concepts to be identified and grouped into categories. The interaction itself is the core category of the grounded theory analysis. It is a process involving events, strategies, outcome and consequences. 
The findings were published in a book titled Reaching Key Financial Reporting Decisions: How UK Directors and Auditors Interact (Beattie, Fearnley \& Hines, 2011) (hereafter $\mathrm{BFH})$. The purpose of the present paper is to summarise the findings of that study, thereby making it accessible through the scholarly journal literature. Developments in the scholarly and professional literatures emerging subsequent to the book's publication are incorporated in the paper and subsequent events and regulatory debates are discussed.

It is shown that the process for reaching agreement on financial reporting outcomes has changed fundamentally under the revised UK regulatory framework, requiring substantial revision to the original grounded theory model. Our findings indicate that regulatory changes, especially the more stringent enforcement of both audit and accounting standards which is a feature of the UK context, have had a profound impact on the quality of interaction outcomes, reducing variability. These changes (enhanced scrutiny and stronger sanctions) apparently created incentives for the key players (including the firms' technical departments) to comply with the accounting standards, irrespective of the perceived intrinsic quality of the accounting outcome. In evaluating individual outcomes under the analytical framework, we define 'quality' narrowly in terms of the applicable regulatory framework, without making any evaluation of that framework. In the case of compliance issues, quality may be equated to compliance. Where an outcome is a matter of judgment it is not always possible to evaluate the quality of the judgment, such as a discount rate, but it is possible to consider an outcome in terms of compliance with the process of reaching the judgment. However, in our broader discussion of the quality of outcomes in general, the broader intrinsic quality is considered, i.e. whether the outcome shows a true and fair view. This is an overriding provision in UK company law to ensure the integrity of financial statements. The application of the true and fair view under the changed regime in the UK remains the subject of controversy between investors and the FRC. In several interactions, there was evidence of a divergence between quality in terms of compliance and quality in terms of true and fair view. One CFO described the outcome from a particular interaction in the following terms, 'It even got to what I regard as a rather silly situation with the auditors where they were agreeing that it didn't make sense but that is what the accounting standard said and therefore that is what you have to do.' Another CFO noted that 
investors are challenging the sense of IFRS: 'Most analysts use figures from...investor presentations... what happens in the statutory accounts is a side show'. Recently, the Local Authority Pension Fund Forum has confirmed the existence of substantial legal problems with IFRS (LAPFF, 2013).

Findings from the UK setting will be of interest to an international audience for a number of reasons. First, the UK is a major capital market and many countries historically adopted UK accounting standards before moving to IFRS. Second, many aspects of the current UK setting are common to other countries (the adoption of international accounting and auditing standards and aspects of the corporate governance regime), suggesting that certain outcome consequences may be found in other settings. However each country offers a unique blend of national and supranational regulation, that influences the particular field logic of the time and hence the behaviour of individual actors. In considering reform, other jurisdictions can be informed by the consequences (desirable and undesirable) of particular regulatory mixes. Finally, this study provides a methodology for assessing the consequences of regulation and regulatory change that could be replicated in other settings.

The remainder of this paper is structured as follows. The next section, the literature review first sets out the changes to the UK regulatory environment since the first study was undertaken, before reviewing the relevant literature on audit interactions. Section three discusses the methods used in the study, section four presents the revised grounded theory model and compares this with the original model. A final section summarises and concludes.

\section{LITERATURE REVIEW}

\section{The UK regulatory environment}

The key changes in the UK regulatory environment that occurred between the two study periods, together with a comparison with the international setting are described in this sub-section. A summary is provided in Table 1. The UK regulatory environment remains fundamentally unchanged from 2007 to the present time although further changes are likely to take place. ${ }^{7}$ 


\section{[Table 1 about here]}

\section{International context and national structures}

Increasingly, national regulatory bodies are interconnected with supranational private sector regulatory bodies at the global level (i.e. the International Accounting Standards Board (IASB) and the International Audit and Assurance Standards Board (IAASB) which functions under the aegis of the International Federation of Accountants IFAC), There are also governmental regulatory bodies at European Union (EU) level such as the European Financial Reporting Advisory Group (EFRAG) which endorses IFRS as suitable for use in the EU (Cooper and Robson, 2006).

This creation of a new institutional field and attendant shifts in regulatory logics are well documented by Suddaby et al. (2007; 2009). In particular, supranational regulators and the global accounting firms have gained power at the expense of national regulators and the professional accountancy bodies, although national regulators and professional associations retain a significant role (Greenwood et al., 2002). In the US, the passing of the Sarbanes-Oxley Act (SOX) (2002) following the Enron scandal introduced major regulatory changes in that country, which were substantially mirrored in many other countries (Lennox, 2009). These changes included, inter alia, independent inspection of listed company audits and a requirement for greater engagement with the auditors by the company audit committee.

In the UK, responsibility for accounting, auditing and corporate governance regulation and oversight falls to the Financial Reporting Council (FRC). Prior to the post-Enron reforms of 2004-5, the FRC's role comprised responsibility for the Combined Code on Corporate Governance and owning three boards (operating bodies), the Accounting Standards Board (ASB), the Financial Reporting Review Panel (FRRP) and the Urgent Issues Task Force (UITF). The post-Enron reforms ${ }^{8}$ incorporated the Auditing Practices Board (APB) and a new body, the Professional Oversight Board (POB) into the FRC. The POB's main roles were to inspect public interest audits, oversee the activities of the accountancy professional bodies and report publicly on these activities. The POB included the Audit Inspection Unit (AIU). Further reorganisation took place in 2012 (FRC, 2013a). ${ }^{9}$ 


\section{$\underline{\text { Accounting standards and enforcement }}$}

International Financial Reporting Standards (IFRS), promulgated by the IASB, were introduced into the EU for the group accounts of listed companies for accounting periods commencing on or after January 12005 (European Union, 2002). Planned convergence of IFRS with US Generally Accepted Accounting Principles (GAAP) was announced in 2002 (Financial Accounting Standards Board and International Accounting Standards Board, 2002), which encouraged the adoption of IFRS in many countries outside the EU. Since then, convergence projects have been undertaken. Full convergence is no longer imminent. The IASB publicly attributes this to failing to agree fully on some projects (impairment and insurance contracts) (IASB, 2013b).

Although IFRS are claimed to be more principles-based than US GAAP, BFH (pp. 2545) find that interviewees viewed IFRS as more rules-based than UK GAAP because it had been heavily influenced by US GAAP as a result of the IASB-US GAAP convergence plans. ${ }^{10}$ This is because the extensive implementation guidance in IFRS is argued to amount to de facto rules (Schipper, 2005). Thus, the role of professional judgment for accountants and auditors was diminished (Bennett et al., 2006).

A key area of judgment that was affected related to the overriding requirement for accounts to give a true and fair view, which was introduced into UK legislation in 1947 under the Companies Act. The concept has never been officially defined; indeed it is commonly argued that a definition would be unhelpful, as the principle is dynamic. In the 1970s, the concept was introduced into the fourth EU company law directive. For useful general discussions of this concept, see Nobes (1993) and Walton (1997). The 2002 Regulation (European Union, 2002) set out certain criteria for the adoption of IFRS standards. One of these was that they should not be contrary to the principles set out in article 2(3) of Directive 78/660/EEC ${ }^{11}$ which established the circumstances in which the requirements of individual accounting standards should be overridden in the interest of providing a 'true and fair view'. However, the overriding UK principle of 'true and fair view' was replaced by a 'present fairly' requirement in IFRS (Evans, 2003. and accounts which complied with IFRS were assumed to deliver a fair presentation. IAS 1, an accounting standard extant in 2005 when IFRS was introduced, refers to the exercise of an override only in 'extremely rare circumstances' (IAS 1, 2003), thereby strongly discouraging departure from IFRS. Richards, an influential investor, 
challenged the risk to the override (Richards, 2005) and the ensuing concerns from others led to the 2006 Companies Act reinforcing its continued importance in Section 393, but this was not applicable until 2009. Interestingly, Livne \& McNichols (2009) find that the use of the override has almost disappeared.

The overall quality of the IFRS accounting model and specific standards have been criticised on the grounds of the unreliability of fair values and complexity (Penman, 2007; Beattie et al., 2008a and 2009a; Bush, 2009; ICAEW, 2007). Following several years of debate, disclosure frameworks for the financial statement notes are being developed to reduce complexity (EFRAG/ANC/FRC, 2012; FASB, 2013; IASB, 2013a). Outside the financial statements, accounting narratives are an increasingly essential supplement and complement positioned at the front of the corporate annual report. Traditionally, narrative reporting in the UK has been mainly voluntary, governed by best practice guidance (ASB, 1993; 2003; 2006). More recently, mandatory elements were introduced to comply with the 2003 EU Accounts Modernization Directive, extended in the Companies Act 2006 (section 417).

The financial accounting enforcement body, the FRRP, first established in 1990, initially took a reactive role, investigating the accounts of companies drawn to its attention. Since 2004, there has been pro-active monitoring of the financial statements of public interest entities and directors' reports have been included in this remit since 2006. Any concerns are raised with the company directors, who are encouraged to consult their auditors and their audit committee. Unsatisfactory explanations by the company require remedial action by the company in the form of a restatement of the financial statements (in which case the Panel may issue a press notice). Failure to comply can lead to court action, although the Panel has not yet had to take this action. Research indicates that the FRRP's activities encourage compliance, even prior to its more proactive role (Fearnley et al., 2002). BFH (pp. 256-258) find that interviewees viewed the FRRP as keeping people 'on their toes' with an investigation being something 'to be avoided'.

\section{Auditing standards and enforcement}

The Auditing Practices Board adopted International Standards on Auditing (ISAs) for 2005 year ends. ISAs are set by the IAASB under the aegis of IFAC. To ensure compliance with UK Company Law, these were slightly amended for use in the UK (APB, 2004a). The APB also has responsibility for setting ethical standards for auditors. 
In a recent UK survey, Beattie et al. (2013) obtain views, from key parties involved in the co-constitution of audited annual reports, on the impact on audit quality of 36 economic and regulatory factors. Nine independent dimensions emerge, labelled economic risk; audit committee activities; risk of regulatory action; audit firm ethics; economic independence of auditor; audit partner rotation; risk of client loss; audit firm size; and, International Standards on Auditing (ISAs) and audit inspection. Audit committee interactions with auditors were considered to be among the factors most enhancing audit quality, although many other aspects of the changed regime were considered largely process and compliance driven. Audit partner rotation rules were viewed to have a negative impact.

Audit firms which have more than ten public interest audits are subject to full scope AIU inspections. The AIU reviews these major firms' policies and procedures in a range of areas and also conducts individual audit reviews, which focus on the appropriateness of significant audit judgments and the sufficiency and appropriateness of audit evidence. The results of these inspections are published in the form of an overall report and reports on individual 'major' audit firms (e.g. AIU, 2012). ${ }^{12}$ In many countries outside the UK, similar systems of independent audit firm review and inspection have been introduced.

Previous research into the audit regulatory space using neo-institutional theory as an interpretative lens is equivocal regarding the role and power of national regulators. Whereas Malsch and Gendron (2011) conclude that, in the Canadian setting, the large global accounting firms wield increasing power over regulatory bodies, Canning and O'Dwyer (2013) conclude, in the Irish setting, that national regulators retain significant influence over regulatory outcomes.

\section{Corporate governance}

A formal corporate governance framework was introduced in the UK in 1992 (Cadbury Report, 1992). Subsequent reviews (Hampel Report, 1998; Smith Committee, 2003) resulted in the Combined Code for Corporate Governance (now renamed the UK Corporate Governance Code) and subsequent revisions to it (FRC, 1998; 2003; 2006a; 2008a; 2010, 2012). The Code operates on a 'comply or explain' basis. The Code provisions relating to audit committees include the requirement to establish an audit 
committee (including necessary member attributes) and the committee's role and responsibilities in relation to monitoring the integrity of the financial statements of the company. These responsibilities were significantly extended following the Smith Committee (2003) and specifically referred to discussions with the external auditor.

This crucial role of the audit committee in engagements between the company and the external auditor is set out in both the relevant auditing standard International Standard on Auditing (ISA) (UK and Ireland) 260 and in the provisions in the Combined Code (APB, 2004b; FRC, 2006b). ${ }^{13}$ Consequently, the existing dyadic model of auditor-client interactions was replaced with a triadic model including the ACC. The CFO takes executive responsibility for preparing the draft financial statements; the AP forms and expresses an opinion on these statements; and the ACC chairs the main board subcommittee which has oversight responsibility in relation to the financial statements.

In summary, therefore, in 2005 the UK, with its vitally important capital markets, effectively lost control of its accounting for listed company group accounts through the EU Regulation and voluntarily ceded significant control of its auditing standards to an international body controlled by the accounting profession. Thus the UK's influence on accounting standard setting for listed companies and auditing standard setting for all companies became downgraded from setting and enforcing its own standards to attempting to influence two bodies with aspirations to be global standard setters. It did, however, retain control over the enforcement process.

The move away from national standards was subject to some early criticism in the UK. In relation to IFRS, the chair of the Financial Reporting Committee of the UK's top hundred finance directors, expressed concerns about (i) significant US influence on potentially global standards (ii) the use of fair value accounting and (iii) the risk of the UK losing the principle of stewardship (Lever, 2005). In relation to ISAs, Richards (2005) expressed concerns about (i) the overall quality of ISAs (ii) the potential downgrading of the true and fair view/override in the UK and (iii) auditing becoming process driven under the prescriptive ISA regime.

It was argued by some that trying to avoid diversity in standards across countries results in a rules-based, rather than principles-based approach (Hoogendoorn, 2006). 
Compliance with such a rules-based approach was paramount in the minds of the standard-setters - in the IASC Annual Report (2007) the Chairman of the Trustees insists that a key objective for the Trustees is 'to promote consistent adoption of global standards' (p.5). This intolerance of divergence from accounting rules is illustrated in the Société Générale fraud case, where the company and the auditors were pilloried in the US press for using a true and fair override to book a loss ahead of what was permitted in IFRS (Norris, 2008; Accounting Onion, 2008). The chair of IASB also emphasised the need for full compliance in evidence to the House of Commons Treasury Committee (2009, questions 202, 207, 209). By 2008 and 2009, quantitative survey evidence from nearly 500 CFOs, APs and ACCs showed that the IFRS and the impact of IFRS on the true and fair view were deemed to be undermining financial reporting integrity (Beattie et al., 2008a, 2009a). In open-ended narrative comments regarding regulatory changes, only 24 of the 289 specific comments about IFRS were favourable, referring mainly to the benefits of global common standards. All groups complained that IFRS were rules-driven and overly complex, calling for a return to principles-based accounting and true and fair.

\section{Audit interaction research and the involvement of the audit committee post-SOX}

Audit interactions research is based upon generic analytical models of bargaining, negotiation and strategising (see BFB, pp. 43-46 for a summary). Behavioural models of the interaction process cover the antecedents and consequences of the interactions as well as the stages of the interaction process and the elements of the process. In a recent review of generic (i.e. not specific to the audit setting) negotiation research, it is concluded that hopes for a universal and simple theory of negotiation have not been fulfilled (Menkel-Meadow, 2009). While the basic elements such as tactics and outcome remain, 'complexification' has arisen from the consideration of, inter alia, number of parties, negotiator continuity, relationships, formal legal requirements, ethics, accountability, and discourse strategies. The specific features of the audit setting that are likely to have a significant impact upon interactions are the highly regulated setting and the unobservability of the process and (frequently) the outcome.

The vast majority of empirical audit interactions research takes the form of large-scale quantitative empirical studies, using archival, experimental or questionnaire research methods. For summaries of archival and experimental research see Nelson (2005) and 
Salterio (2012), respectively. While most experimental studies focus on the auditor-CFO dyad, a few recent studies explore the influence of audit committees on negotiation (Pomeroy, 2010; DeZoort et al., 2008).

Experiential questionnaire studies elicit respondents' experience of the incidence of interactions, the tactics employed and the outcomes. Respondents are APs (Beattie, et al., 2000 and 2008b in the UK; Gibbins et al., 2001 in Canada), CFOs (Beattie, et al., 2000 and 2008b in the UK; Gibbins et al., 2005 and 2007 in Canada) and, most recently, ACCs (Beattie, et al., 2008b in the UK). These studies have revealed substantial consistency in the responses of these groups. In the only study to date to cover the CFO / AP / ACC triad, Beattie et al. (2008b) survey a large sample of UK listed company CFOs, APs and ACCs about their recent experience of discussions and negotiations on 35 financial statement issues (see Appendix 2 for definition of these terms). 498 usable responses were received, representing a response rate of $36 \%$. Respondents were asked to indicate which of the issues had been the subject of discussion and/or negotiation in the latest financial year. There was a high level of consensus across the three groups. On average, 11.3 discussion issues were reported and 1.7 negotiation issues. These interactions have a significant impact on the final published financial statements, with the accounting numbers being changed for 1.5 issues (on average) and the disclosures being changed for 2.4 issues (on average). The issues most frequently causing interactions related to business combinations, segmental reporting, deferred tax, presentation, the Business Review ${ }^{14}$, revenue recognition and exceptional items. ${ }^{15}$

Neither analytical models nor any one of these three empirical methods are, however, able to capture the richness and complexity of the interactions that has been revealed by grounded theory studies based on in-depth qualitative research such as BFB. In this ground-breaking study, BFB conduct matched interviews with the CFOs and APs of six major UK listed companies. From this evidence, covering 24 distinct interaction issues, a grounded theory model was developed of the negotiation process and the factors that influence the nature of the outcome of interactions. The principal analytical categories in this model, arranged in five groups around the core category - the interaction itself, are shown in Figure 1. The most distant group of influences was the global regulatory climate, followed by the external national trading and regulatory climate, general contextual factors, specific contextual factors and the interaction itself. General 
contextual factors comprised the quality of the primary relationship, company circumstances, audit firm characteristics and circumstances and the company buyer type. The specific interaction context covered, in particular, the substantive issue that was the subject of the interaction, the objectives of the parties, and the identity and role of key third parties. Categories associated with the interaction itself were events, strategies, outcome and consequences.

[Figure 1 about here]

This approach has since been replicated in the 2001 Canadian context based on eight matched interviews (McCracken et al., 2008), with broadly similar results. Some CFOs initiate a proactive relationship, where the CFO consults the audit partner as 'expert advisor' at an early stage to ensure high quality financial reporting. Other CFOs took 'ownership' of the financial statements, seeing the audit partner as a 'police officer'. In both cases, the parties worked together to find a resolution to the issue and the audit partner sought to 'keep the client happy'.

The interview study summarised in the present paper was conducted in the 2007 UK regulatory environment, and complements the limited extant large-sample research on the CFO / AP / ACC triad (Beattie et al., 2008b). Revisiting the approach of BFB in the context of the much changed 2007 / 2008 post-SOX UK regulatory framework, BFH (2011) report on nine UK listed company case studies covering entities of different size and employing different auditors and interviewing CFOs, ACCs and AP. Subsequently, this approach has been replicated in Malaysia by Salleh \& Stewart (2012).

\section{Audit committee processes research}

Of additional relevance to this study are a number of interview studies which explore audit committee processes without looking specifically at the role of the committee in interactions. ${ }^{16}$ In a quantitative interview study regarding the actions and behaviour of audit committee members, Beasley et al. (2009) explore the audit committee oversight process in the post-SOX US setting by interviewing audit committee members, finding evidence of both substantive monitoring (consistent with agency theory) and ceremonial action (consistent with institutional theory and the earlier UK findings of Spira (1999)). Cohen et al. (2010) interview Big Four US audit managers and partners to explore their 
experiences in interacting with management and audit committees. Audit committees are believed to have become significantly more active and diligent, and to possess greater expertise and power, although they normally played a passive role in helping to resolve disputes (a finding consistent with Gendron \& Bédard (2006) in Canada). In a single case study set in the UK, Turley and Zaman (2007) find that the audit committee has a significant influence on power relations between key actors and is used as a threat, ally or arbiter in resolving issues and conflicts.

In a review of studies of the relationship between audit committee characteristics and audit committee effectiveness, Bédard \& Gendron (2010) conclude that audit committee existence, members' independence and members' competence all influence effectiveness positively, whereas the number of meetings and the size of the committee have no significant impact. They lament the lack of research conducted outside the US, calling for research into the dynamics of audit committee processes. The review by Cohen et al. (2007) into auditor communications with the audit committee and main board concludes that communications between the auditor and the audit committee should include discussions of areas susceptible to earnings management and also factors that may drive management to make aggressive accounting choices. Interestingly, Beattie et al. (2012) report that individuals attend audit committee meetings as non-members - CFO (94\%); CEO (75\%); internal auditor (65\%). Other frequent attendees included the company secretary, the financial controller; the head of risk; and the head of compliance. In some cases, other directors (including the chairman) also attended. This suggests that complex group dynamics may be at work.

In summary, there have been major changes in the UK regulatory environment between 1997 (the date when data for the BFB was collected) and 2007 (the date when data for the BFH study was collected). As summarised in Table 1, there was a shift from principles-based UK GAAP to relatively more rules-based IFRS, reducing the role of professional judgement in relation to accounting matters. Auditing standards also became more rules-based. The accounting and auditing enforcement bodies became more visibly active and the role of the audit committee was extended under the corporate governance code revisions. In depth, qualitative research undertaken in the 1997 UK regulatory context (the BFB study) indicated that general and specific contextual factors had more influence on the nature of interaction processes and outcomes than either national or global regulations. The BFH study examines whether this finding still holds 
following major regulatory changes that includes the growing influence of the audit committee.

\section{METHODS}

\section{Case selection and interview procedures}

The nine cases were identified from the Beattie et al. (2008b) questionnaire study. As part of the questionnaire, respondents were asked if they were willing to be interviewed (39 CFOs, 78 APs and 33 ACCs agreed in principle). Target companies were carefully chosen to reflect different sizes, industry sectors and audit firms, including all the Big Four firms and two other firms. As data analysis progressed, these nine cases and their related interactions were judged to have resulted in theoretical saturation, hence no further cases were sought. The CFO or ACC from the target company who had agreed to be interviewed was approached personally and the case study project was explained, including our requirement to interview all three parties, and offering unconditional assurances of confidentiality. To interview the AP we required explicit permission from the company interviewees. ${ }^{17}$ We obtained permission to approach the CFO, AP and ACC in nine companies. ${ }^{18}$ It was a very protracted process to obtain the access and permissions necessary to secure this set of matched interviews.

All interviews were recorded (with permission) and subsequently transcribed. The interviews were conducted with each individual separately apart for one company where the interview was joint with all three parties. In another case the ACC withdrew from the study at a late stage. We undertook to contact the interviewees when we had written up the results of the interviews to give them the opportunity to comment in order to ensure that the company could not be identified from the story. All the interviews were jointly conducted by two of the principal researchers to ensure consistency of approach. As well as being experienced academics in qualitative research, both researchers also had experience of auditing listed companies and were therefore conversant with the process and issues being discussed. In preparation for each meeting, the company's annual report for the period covered by the questionnaire was obtained and studied and recent press reports were also reviewed. This enabled the researchers to become familiar with the nature of the company and activities, its approach to corporate governance and accounting issues that appeared to be significant. Relevant questionnaire responses, 
where available and where the respondent was identifiable (not the case for APs), were also reviewed to form an agenda for the interviews.

As the issues arising in each case were different, there was no fixed series of interview questions. Interviewees were asked to (i) describe how the relationship between the three parties and the audit committee worked in practice in their company (or client) and (ii) talk about the issues that had given rise to interactions (discussions or negotiations) with either of the other two parties and how they viewed the progress of the issue to its final resolution. Not all interviewees from the same company commented on the same issues, however the interviewers gave no indication to the interviewees of what the others had said.

The interviews employed both neutral, conversational prompts and a laddering technique. This technique requires that the interviewer keeps asking for further clarification, working backwards to antecedent conditions and forwards to anticipated effects (Brown, 1992). Examples of prompts used were:

- Who first raised the issue?

- What form did the discussions take?

- Was the ACC involved? At what stage?

- What role did the audit committee play?

- Were any threats or promises made?

- Were you happy with the outcome?

- Did the outcome affect subsequent relations?

Where appropriate, reference was made to the company's annual report to obtain further assurance regarding the trustworthiness of the evidence collected (Lincoln \& Guba, 1985; Yin, 2008). No inconsistencies were found between the annual report and the interviews. All the interviews were recorded and fully transcribed and lasted between one and three hours. With the exception of two interviews, which were carried out in hired private office rooms at the ICAEW premises, all interviews were carried out at the client's premises, wherever located. The interviews were carried out between December 2007 and April 2008. However the interviews for each case company were held as close together as possible and companies were approached in succession. 
The approach to the analysis follows that adopted in Behind Closed Doors and Reaching Key Financial Reporting Decisions and is consistent with the grounded theory methodology of Corbin \& Strauss (2008). Grounded theory refers to the process of building theory inductively from the analysis of data. The approach focuses on a core phenomenon or incident and seeks to understand it, by constantly comparing the data at different levels of abstraction. This is undertaken by coding key features in each text and grouping these into concepts that apply across-cases. Similar concepts are further grouped into categories and the relationships between these categories form the final grounded theory. ${ }^{19}$ In the type of grounded theory applied in the present study, researchers are permitted to be open to prior theory ${ }^{20}$ and the analytical procedures are well-defined.

The interaction is the core phenomenon. In exploring this phenomenon, theoretical sensitivity emerged primarily from our systematic review of the relevant theoretical literature. This allowed us to maintain an awareness of the subtleties of meaning of data and suggested concepts and relationships that were assessed against the data collected. In addition, the rigorous procedures and techniques used in the analytical process, similar to those followed in BFB, were expressly designed to test and modify the grounded theory of BFB. However, whereas the study by Beattie et al. (2001) was generating grounded theory, the study summarised here sought to test and if necessary modify that theory. Grounded theories are evaluated in terms of their fit, relevance, workability and modifiability (Glaser \& Strauss, 1967). Therefore, the existing grounded theory concepts were systematically tested against the new data to establish which concepts still appeared to have influence and whether the influence had changed. We also sought to identify new concepts evident in the data, some of which may exist in the prior literature. In examining and re-examining each interaction, causal conditions, context, intervening conditions, action strategies and consequences were sought (Kelle, 2005).

The analytical approach comprised four stages. First, the stories in each case were described. To do this, each printed interview transcript was coded using themes which emerged from repeated reading of the matched interviews from the existing grounded theory of BFB. The drafts of the stories were written up to include a brief overview of the companies followed by the interviewees' descriptions of how the relationships between them and the audit committee worked in practice. Thereafter, the main 
interactions were written up individually as a chronological story reflecting the different perceptions of the interviewees who commented on the specific issues (Hansen \& Kahnweiler, 1993). Each interviewee in the case company was invited to comment on the draft story. The interviewees' reactions to the stories ranged from contentment for us tell it as it was, provided the company was not identifiable, to great sensitivity either about the relationships or the risk of identification. In most cases where concern was expressed, modest rewriting satisfied the parties. However in one case the CFO and ACC did not want the detailed story to be included and in another no verbatim quotes were permitted. Interestingly, in both of these cases, the CEO or chairman of the company had intervened.

The second analytical stage was to conduct within-case analysis using close reading methods based on the grounded theory developed in BFB. This first required a classification system to be developed to allow common labels to be associated to the key concepts identified in each case. Descriptive concepts provide background information about the nature of the company's activities, the role and function of the audit committee and the ACC and how the three interviewees viewed their roles in the governance process. The local contextual factors that might influence the nature and outcome of the interactions included the size of the company, the size of the audit firm, the quality of the relationships between the CFO, ACC and AP (graded poor to good), the attributes of the audit committee (e.g. number of members, other attendees, financial literacy of ACC, number of meetings per year, degree of contact outside the meetings) and the company reporting style, classified in terms of compliant/non-compliant and conservative/aggressive. The general contextual influences relate to the regulatory environment and the economic climate.

Interactive concepts describing the discussions and negotiations which took place were labelled interactions. Interactions are classified according to their form (discussion or negotiation). The 45 financial reporting interactions were classified using the fivefold BFB scheme: recognition; measurement; classification; disclosure; and fundamental accounting principle. There were two possible decision types: compliance (where the regulatory framework prescribes how the issue should be treated) and judgment (where no prescriptive pronouncements can be made although a process for making the judgment was set out in the relevant accounting standards). Interaction could be 
characterised by a mixture of these decision types. The results of the interactions were labelled outcomes The outcome of compliance issues were classified as compliant or non-compliant. Judgment issues were evaluated in terms of compliance with the process of reaching the judgment.

Using these labels, the local contextual factors that appeared to influence the nature and outcome of all the interactions in a case were first identified. Thereafter, each interaction was analysed separately, looking for local context, causal conditions, intervening conditions, tactics and strategies and consequences. Based on close reading (and rereading) of each interaction story, we sought to identify the critical influences upon the outcome. Although this assessment is inevitably subjective, the extensive quotes given in the book from each of the three parties do support the judgements made. This analysis allowed the fit of the existing grounded theory to each interaction to be assessed. Throughout, diagrams were used as an analytical aid to represent relationships between concepts and categories.

The third stage of analysis comprised cross-case analysis. To begin this stage, the interaction attributes of each of the 45 interactions were summarised. That is, the frequency of each issue type, interaction type and decision type was noted. Thereafter a detailed tabulation of each interaction was constructed to show, in addition to the interaction attributes: nature of issue; interaction context, form of interaction and tactics adopted; involvement of ACC and full AC; and outcome attributes (quality and ease of agreement).

Finally, testing and modification of the original theory was undertaken from the crosscase analysis, drawing on the importance and role of each identified concept.

\section{Trustworthiness of interview evidence}

Two specific features of the study provide the reader with reassurance on the trustworthiness of the interview evidence (Lincoln and Guba, 1985). First, the study replicated the methods, questions and research team of the BFB study of ten years previous. The previous study did throw up many interactions where there was conflict and intense negotiation between the parties and can be viewed as a natural control - the only aspect of the research that has changed are aspects of the setting and hence the 
nature of the behaviours. Second, these were matched interviews and the three parties separately offered three broadly consistent stories of the interactions.

\section{RESULTS AND DISCUSSION}

This section begins by outlining the general descriptive features of the set of financial reporting interactions discussed by participants and the general nature of the relationships between triad members and other key actors. Thereafter, participants' views of the regulatory setting are briefly summarised. The revised model of the interaction process and outcomes is then set out and compared with the original model.

\section{General descriptive features of interactions, $A C(C)$ competences and relationships}

A total of 45 financial reporting interactions were identified across the nine case companies. $^{21}$ Recognition/measurement issues (i.e. issues with both recognition and measurement aspects) and disclosure issues were the most frequent issue type (equal top rank), followed by measurement issues. Together, these accounted for the majority $(70 \%)$ of the financial reporting interactions. The recognition/measurement category is split approximately equally between discussions and negotiations. The disclosure issues were all discussion interactions. A number of issues occurred in several cases: identification / valuation of intangible assets on acquisition (five cases), inventory valuation (four cases) and Business Review (five cases). At the time the Business Review was an impending new legal requirement, therefore interactions involved the decision as to whether to adopt early and, if so, the content, tone and coherence with the financial statements. In terms of decision type, $69 \%$ of the decision types were judgments in terms of the accounting standards, $11 \%$ were pure compliance and the remaining $20 \%$ were a mixture. Compliance decisions were more likely to result in a negotiation interaction between key parties. Notably, however, the overall frequency of negotiation was lower than in the BFB study.

IFRSs are complex and many ACCs do not immediately have to hand the requisite technical accounting knowledge to understand the accounting issues that arise. Although one ACC interviewee believed that (s)he was up-to-date ('I have been a FTSE 100 finance director. I have stayed up to date. I actually work quite hard staying up to date. '), this individual was in the minority. One ACC interviewee offered the following 
view: 'Most of us wouldn't even pretend that we are up to speed with the latest international standards. If the audit committee members are wasting time debating the finer principles you are probably off the track anyway.' However these individuals appeared to recognise their limited knowledge and seek out the relevant knowledge when necessary - 'if they don't understand something, they will ask' (Big Four AP). Since most ACCs have an accounting background, they are able to understand the subtleties of issues once they have the relevant knowledge and in a position to explain the issues to fellow AC members. One CFO remarked, 'they are not accountants and they are not familiar with IFRS. So my understanding is that they very much let [name of ACC] lead them on the technical issues'. This situation has increased the extent to which non-accountant AC members rely on the ACC.

Corporate governance changes relating to the role of the audit committee have transformed the predominant dynamic in financial reporting interactions from a dyad (CFO and AP) to a triad (inclusion of ACC). One ACC interviewee described the relationships as follows: 'in essence you are a thermometer which tests the temperature of the finance director in particular... I think the new triangular model, as opposed to the old binary model, where the audit committee comes to the party last, is definitely a vast improvement on how things were in the past'. ACC interviewees did not consider that either the ACC as an individual or the full audit committee should resolve disputes between the AP and the CFO. An ACC explained this in the following terms: 'The last thing the audit committee wants, even nowadays, is to be cast as arbiter. It is one thing to be involved in the discussion, another to say I would do this. They are poorly placed to make that kind of executive decision... Most of us wouldn't even pretend that we are up to speed with the latest international standards'.

ACCs expected to be informed of emerging issues and for the CFO and AP to present an agreed proposal on accounting issues to the audit committee for them to challenge and/or approve. Thus, there was regular communication outside the audit committee meeting between the ACC, the AP and the CFO and between the ACC and the audit committee. This communication process was described by one ACC as follows: 'I think that as audit committee chair I sit down with the finance director and with audit partner separately and I say 'What problems do we have and what problems can you foresee?' because they are the ones that we should tackle before we get there'. The ACC generally 
played a key role in managing the relationships within the triad as they are in a powerful position and effectively oversee the CFO and AP. This finding contrasts with that of McCracken et al. (2008), who conclude in relation to the CFO-AP dyad in the Canadian setting that it is the AP who has responsibility for managing the relationship in order to keep the client happy.

The evidence suggests that this new dynamic has changed the power relations among the key parties. In the previous dyadic relationship, power struggles could erupt between the $\mathrm{CFO}$ and $\mathrm{AP}$ (see BFB). In the changed environment, both the $\mathrm{CFO}$ and $\mathrm{AP}$ are accountable to the ACC, who is responsible for managing the AC, which finally approves the financial statements before they go to the main board. Additionally, the presence of other directors at audit committee meetings (Beattie et al., 2012) means that neither a CFO nor an AP would wish to expose an unresolved disagreement at these meetings, thereby risking loss of face and personal reputation damage. Based on analysis of the interview evidence, these corporate governance changes, combined with the strength of the enforcement bodies, have caused the ACC (and audit committee) to gain power on accounting and auditing matters at the expense of the CFO and AP. IFRS complexity has delivered more power into the hands of the technical departments of the audit firms. This power shift towards technical departments was described by one CFO in the following terms: 'But now there is a certain amount that the audit partner can agree himself, which I think in reality is pretty small, pretty routine stuff. The big stuff, they immediately go to the technical department. I would never have dreamt ten years ago of asking the audit partner if he had authority'.

These findings support the findings of Cohen et al. (2008) and Gibbins et al. (2007) that audit committees play a passive role in dispute resolutions in the sense that resolution is sought before the matter comes to the audit committee's attention. However, neither Cohen et al. (2008) nor Gibbins et al. (2007) explore the role of the individual ACC, leaving a lacuna in our understanding of audit committee practices. While Gibbins et al. (2007), find that the CFO may not keep an AP informed of accounting issues at the decision making stage, because of feelings of ownership of the financial statements, the present study finds that the engagement of the ACC changes behaviour as both parties need to keep the ACC informed and the CFO no longer has sole ownership of the financial statements. The role of the audit committee and the ACC as a mechanism to 
control the relationship between the CFO and AP is also consistent with the findings of Beasley et al. (2009) who refer to a monitoring and a ceremonial role for the audit committee. However the present study develops our understanding of this role in a significant way - while much of the monitoring is undertaken by the ACC the ceremonial role remains primarily with the audit committee. The findings also support Coffee's analysis (2006) that the audit committee acts as a gatekeeper, although the present study extends this analysis by indicating that the ACC is also a gatekeeper for the audit committee (see also Beattie et al., 2014). There are, in effect, two distinct 'gates' or filters before issues are considered by the full board.

\section{Key parties' perceptions of the regulatory environment}

Interviewees did not believe that the introduction of IFRS had improved the quality of UK financial reporting, due to excessive complexity, high disclosure volume and increased emphasis on rules rather than principles. One AP commented on the complexity of IFRS as follows: 'They have massively over complicated things to the extent that the number of people out there who really do think they understand a set of accounts is tiny. Your average investor in the market wouldn't have a clue'. Excessive disclosure volume was highlighted by one CFO as: 'I think there are huge amounts of worthless disclosure that nobody ever reads. I have never had a question from analysts on any of the detailed disclosures, so who is it for if it is not for the analysts?'. A typical comment on the rules-based nature of IFRS was: There are times I will get tripped up in IFRS because it is so rules-, not necessarily logic-based...You have to go through the volumes from cover to cover'.

Some standards were considered to produce dysfunctional results and to require costly information collection that was subsequently ignored by users (e.g. the unreliability of fair values; the threat of a rules-based system to the true and fair view; and the requirement to recognise separate intangible elements in business combinations). These detailed comments from interviewees are consistent with the views from the larger questionnaire study (reported in Beattie et al., 2008a and 2009a).

Although ISAs were a less prominent feature of the cases, views were expressed that they, like IFRS, were overly detailed and prescriptive. Some aspects of audit ethical standards were considered to be problematic. The five year rotation period for APs (the 
period extant at the time of the study) was considered by many interviewees to be too short, potentially resulting in reduced audit quality (in line with the large-scale study findings of Beattie et al., 2013), especially in the case of large, complex companies where other key parties in the triad had also changed. An optimal rotation period must achieve balance between the need for an auditor to develop understanding of the business (which takes time) and the desire to avoid allowing time for an overly cosy relationship to develop. The restrictions on non-audit service provision presented some challenges, particularly for small cap companies with fewer accounting resources who were no longer able to obtain accounting and business advice from their auditor at a time when the complexity of IFRS greatly increased their need for advice and support (see Beattie et al., 2009b for further details).

The FRRP was considered to be an effective financial reporting enforcement body and all key parties have strong incentives to comply with standards. For example, one CFO questionnaire respondent commented, 'I think everyone is running scared of a Financial Reporting Review Panel investigation... I have had experience of them .... and it is an unpleasant experience.' The procedures of the AIU (the enforcement body for auditing standards) were considered to be process-driven and based on box-ticking; however, it was still considered a strong regulator and APs were most anxious to avoid adverse reports. For example, one AP questionnaire respondent commented, 'It is a much [more] effective review than the firm's internal processes in my view.' Further supporting quotes can be found in BFH, pp.256-8 for the FRRP and pp.262-264 for the AIU. The fear of review and inspection was based on a mix of direct experience (for some interviewees) and perception (based on indirect experience within the firm, other anecdotal evidence and evidence formally in the public domain). Although the AIU appears to have reduced drastically the scope for bad audit, the nature of the procedures (i.e. the strong enforcement of compliance) may, in conjunction with other aspects of the regulatory framework (dysfunctional standards), have helped to reduce the scope for very high quality audit as well. As with the concept of quality in relation to interaction outcomes, there are two distinct notions of audit quality. The first, narrower concept equates quality with compliance with the applicable auditing standards and ethical standards for auditors. A broader notion of audit quality would step outside the (potentially imperfect) rules to consider inherent audit quality which might include, for 
example, consideration of the auditor's ability to offer advice and to ensure financial reporting outcomes which give a true and fair view.

Key parties viewed IFRS as complex and, in some cases, dysfunctional, while the accounting and audit enforcement bodies were viewed as being strong. These perceptions conditioned the behaviour of the key parties when faced with financial reporting interactions. Despite reservations regarding the quality of some IFRS, the perception that non-compliance risked discovery and severe penalties engendered a compliance mind set.

\section{Process and outcomes}

\section{Overview of revised interaction model}

The extended summary table of all 45 financial reporting interactions (BFH, Table 16.3, pp.284-303), which is described in the methods section above, underpinned the crosscase analysis. (Table 2 includes selected features of this table.) A similar set of categories and category groups emerged during the analytical process to those identified by BFB. The extent of influence of the category groups, together with the specific categories within each group had, however, changed very significantly. Prior to discussing each category individually, it is helpful to present an overview of the theory in the form of a 'conditional matrix' (Corbin \& Strauss, 2008). Figure 2 represents the category groups as a series of embedded rectangles, with each group representing a set of conditional features acting upon the core category (the interaction). The interaction category group comprises four categories: events, strategies, outcome and consequences. The proximity of the category groups to the core interaction is of particular significance as this distance indicates the strength of influence on the interaction. The revised model comprised five main category groups: general company/audit firm context; specific interaction context; international regulatory regime; national regulatory regime; and the interaction itself.

[Figure 2 about here]

The categories impacting most directly on the core category of the interaction itself relate to the regulatory regime, both the standard-setting regime and the enforcement regime and for both accounting and auditing. Whereas the accounting and auditing 
standards are essentially international (the UK exerting only marginal control), the enforcement regimes, together with the corporate governance regime (particularly relating to the role of the audit committee), is specific to the UK (although similar elements are to be found in other countries due to international influences). The field evidence indicates that it is the national enforcement regime which lies closest to the core category group, i.e. the interaction itself. The pervasive and strongest aspect of the mindset of the triad members was a wish to comply with the extant standards and thereby not risk the consequences (both direct and indirect) of either FRRP or AIU adverse reports or corporate governance code violations.

Each principal category in the revised model is now considered in detail, beginning with the most peripheral.

\section{General company/audit firm context}

The influence of this category on the nature and outcomes of interactions was extremely weak in the revised model. The more complex three-way primary relationships placed pressure on all parties to ensure that the relationships work. Audit partner rotation rules (maximum period of five years) also limit the length of these relationships. Consequently, personality and age-related concepts rarely featured as an interaction influence. Additionally, all three key parties shared the same objective of compliance with the regulatory framework, such that professional integrity (levels of each party and alignment between the parties) was not perceptibly influential - compliance took priority in all cases. In other words, the key parties were prepared to accept what they viewed as a less than optimal outcome in terms of the true and fair view outcome, even if they felt uncomfortable with that outcome. The compliance culture that operated at the micro level on the mind-sets of the key individuals scaled up to the meso level of the organisation (both corporate and audit firm). Thus, company circumstances were hardly mentioned by interviewees, indicating a minimal impact on the interactions. Reporting style differences were not apparent. The company buyer type (a taxonomy introduced by Beattie \& Fearnley, 1998) consistently in evidence across all cases was comfort-seekers, mixed with resource-seeker in the case of smaller companies with limited IFRS expertise. The degree to which accounting support can be provided by the audit firm has, however, been considerably reduced by auditing ethical standards (APB, 2004c). 
In relation to the audit firm, key support and monitoring infrastructure elements, such as second partner review; technical review and peer review, are now mandatory for audit firms. This reduces the extent of observed variation. The professional integrity of the AP has become subsumed within the overarching compliance culture. Personal integrity, viewed as behaviour extending beyond the standard required by professional ethics, was rarely evident, as it met with resistance and brought double jeopardy from the FRRP and the AIU. APs wanted no engagement with regulators, and noncompliance risked enforcement intervention, irrespective of whether the non-compliance was due to unethical behaviour or use of the true and fair view override. Consequently, all nine APs could be described as the 'safe pair of hands' AP type (BFB, pp. 275-6). No 'crusaders' were in evidence, though neither were 'accommodators' or 'trusters'.

\section{$\underline{\text { Interaction context }}$}

IFRS adoption introduced more complex process-driven judgments into a number of key interaction issues such as intangible valuations and share-based payments. In line with the general shared objective of the triad members, the primary goal for each issue to arise was to ensure regulatory compliance and thereby avoid trouble. Secondary specific objectives of individuals in some cases included face-saving (when an investment was being reviewed for impairment).

Prominent influential third parties were the technical departments of the audit firms (directly involved in at least ten of the interactions). The audit committee was also frequently involved in the interaction, generally at the final stage when they formally 'reviewed', 'discussed' or 'considered' proposed solutions and 'approved' these. The audit committee had an active role in only three cases (twice being used as a forum for resolving the issue and in one case initially arguing against the proposed treatment). In two cases the audit committee was merely 'informed' of the interaction outcome.

Other directors were sometimes influential, either individually (usually the Chairman or CEO) or as a main board. This involvement, which was typically indirect, stemmed from their anticipated reaction to reported outcomes. Other company managers were drawn into a few specific issues, as were previous auditors, subsidiary company auditors, partner firm in another country, other audit firms and lawyers. Accounting practices in other companies occasionally offered a precedent - one CFO reflected that 
'I was quite annoyed. I felt that they were doing one thing for another client, why were they not doing it for us'. CFOs in particular anticipated the reaction of analysts to the reported financial statements.

Other specific contextual factors to have a significant influence in a small minority of cases were time pressure (two instances), the impact on future accounting periods (four instances) and poor communication by a key party (two instances).

\section{International regulatory regime}

In the face of the strong compliance objectives held by the key parties, the quality of the standards and regulations being enforced will be the dominant influence on the quality of the final outcomes. Both the accounting standards (e.g. IFRS set by the IASB) and the auditing standards (ISAs effectively set by the International Auditing and Assurance Standards Board but amended for the UK by the APB) are set by international bodies. Both sets of standards are considered to be rather more detailed and rules-based than the UK standards they replaced and to preclude invocation of the true and fair view override. Even where adherence to the accounting standard was deemed to produce dysfunctional financial reporting outcomes (i.e. misleading or not cost-beneficial) the compliance culture prevailed, resulting in a 'silly situation'.

The complexity of the standards impacted on the interactions, making APs more reliant on their technical departments for the interpretation of standards, creating a power shift within the firms from APs to technical departments. The complexity also made CFOs more reliant on auditors and made audit committees reliant on audit committee members with accountant expertise (usually the ACC). The mean number of audit committee members reported to have an accounting qualification in Beattie et al.'s (2012) questionnaire study was 1.6; the mean number of audit committee members was 3 .

\section{National regulatory regime}

The FRRP was viewed as an active financial reporting enforcement agency likely to identify non-compliance, significantly curtailing the appetite for negotiations. The auditing enforcement agency (the AIU) was especially prominent in the mind-set of APs, since a poor review could adversely impact an individual's career prospects. The 
activities of these enforcement bodies thus created a compliance mind-set and resulted in a process-driven approach to auditing and therefore reporting.

\section{Interactions (core category)}

Observed interaction events included: the provision of information justifying the accounting numbers proposed (frequently used to support judgments by the CFO and not normally challenged by AP); seeking of third party opinions (especially where there was a high degree of uncertainty involved); joint solution- seeking (particularly for complex and unique issues); and acknowledgment of a mistake (one instance). The joint solutionseeking perspective was described by one ACC as follows: 'We are a threesome working together, we have got a common objective which is truth and fairness and all the rest of it. Some of the literature sort of talks as though you are spies on each other, trying to catch each other out. I don't believe that, I think we are there trying to help each other, trying to resolve problems before they get there'.

In terms of strategies adopted, APs often stated their position firmly at the outset of an interaction for compliance issues, thereby adopting an assertive strategy involving the use of a direct and forceful approach. The use of sanctions and threats as strategies were not generally used. Any decision to put the audit out to tender would require audit committee approval under the Combined Code. The audit qualification threat was invoked in one issue when all other methods of communication had failed. There was no evidence of ingratiation strategies being employed, however reason was routinely employed as a strategy (in particular, the use of evidence to support a reasoned argument). There was no evidence of the reciprocity-based strategy (i.e. strategic give and take concessionary strategy) identified by Hatfield et al. (2008) and Sanchez et al. (2007) in the US environment. The ACC ensured that the audit committee was rarely in a position of arbiter. Both the CFO and the AP frequently appealed to a higher authority to confirm their position. This higher authority was typically the audit firm's technical department, but also included a specialist adviser engaged by the auditors, another audit firm consulted by the CFO and a precedent established by another reporting company.

The interaction outcome quality is a dichotomous variable for compliance issues (matters of fact), but it is a continuous variable for matters of judgment. The ease of agreement outcome dimension (a continuous variable) captures issues such as: number 
of parties involved, number of interaction stages, and use of strategies that undermine ongoing relationships. The consequences of interactions included the impact on ongoing accounting interactions, future accounting periods, audit fee negotiations or the quality of a primary relationship.

The 45 financial reporting interactions clustered into six outcome groups. Interactions in the largest cluster (which captured $49 \%$ of all interactions) were both acceptable (in the narrow, compliance with regulation conception of financial reporting outcome quality) and easy to agree. Valuations and impairments generally fell into this cluster (seven easy outcomes and two difficult outcomes). The typical pattern was that the AP would question the value proposed by the CFO, the CFO would undertake more work and present evidence and this would be accepted by the AP and the audit committee. The primary consideration was whether the CFO effectively demonstrated that they had complied with the valuation process, given that it was very difficult to question their judgment based on a superior understanding of the business. Due to the inherent uncertainty of the valuation, the assistance of an independent expert was sometimes sought. In the Canadian context, Smith-Lacroix et al. (2012) conclude that the use of independent valuations in fair value accounting has crowded out the judgement exercised by auditors. Other interactions in this cluster commonly involved judgments relating to disclosures where IFRS provided little guidance (Business Review, segmental reporting and re-organisation costs). The tension often arose from the company's wish to frame disclosure with investors' reactions in mind.

Two clusters each contained $16 \%$ of the interactions. One included outcomes that were compliant and easy to agree. The AP's tactic was, typically, to state his position firmly at the outset, pointing to relatively clear rules in the accounting standards. In the context of strong monitoring and enforcement mechanisms, the APs used an assertiveness strategy in relation to the compliance issues.

The other cluster containing $16 \%$ of the interactions included judgment outcomes that were acceptable, but attained with difficulty. The difficulties arose from the complex and unique nature of the transactions (little guidance offered by the regulatory framework), sensitivity (in relation to board members or commercial impact) and disagreement over preferred treatment. 
The next largest cluster contained compliant outcomes which were attained with difficulty (11\% of all interactions). Although the requirements of the relevant accounting standard were fairly clear for all of these issues, either the CFO or another individual in the company challenged the rationale and impact of that standard. Two of the interactions related to the recognition and valuation of intangible assets on acquisition, two related to the treatment of financial instruments, and the other interaction involved share-based payments. In individual interactions the basic disagreement was exacerbated by the perceived poor communications by the AP and by time pressure to obtain a resolution. This served to protract the interaction. The audit committee was the forum for resolution in two cases. The compliant outcome can be attributed to the strength of the regulatory regime.

Two clusters each contained 5\% of the interactions. One of these included two interactions (from the same case company) where an acceptable judgment outcome was attained with slight difficulty. The relationships between the AP and both the CFO and ACC were not very good in this case - the AP challenged the CFO's judgment with respect to a valuation. The CFO produced external evidence to support his valuation which was then accepted by the AP.

The remaining small cluster of two contained interactions that were compliant outcomes attained with slight difficulty. Again, these arose from a single case company. The interactions related to restatements to the previous year's accounts. Both the $\mathrm{CFO}$ and the AP were newly appointed and so had no face-saving agenda. However the audit committee could have had such an agenda as they had approved the previous treatment. This lack of congruence in the objectives of the key parties created the slight difficulty.

The most striking aspect of the entire set of 45 financial reporting outcomes was that none of them was considered non-compliant or unacceptable. This finding stands in marked contrast with the findings of the Behind Closed Doors study, where there were a number of outcomes that were unacceptable due to non-compliance with the prevailing regulatory framework and/or dysfunctional. This confirms that the dominant influence on interaction outcomes was a generic influence, i.e. the regulatory environment (international and national) and, in particular, national regulatory enforcement. Local 
contextual factors (general and specific) have no discernible impact on 'quality' and only a minor impact on ease of agreement.

\section{Comparison with $B F B$}

It is apparent that, compared to the original model of BFB (see Figure 1), broadly the same category groups are represented. However new concepts have emerged, the significance of established concepts has changed and relationships have altered. In particular, a comparison of Figure 1 with Figure 2 reveals the complete inversion of the relative influence of local contextual factors and regulatory factors. In Figure 1 the two outermost, peripheral categories (which have the weakest and most indirect influence on the interaction) capture the regulatory environment. The two categories closest to the core interaction capture local contextual factors. By contrast, local contextual factors are relegated to the periphery in Figure 2 and regulatory factors emerge as the dominant influence in the revised model.

In relation to the tactics and strategies adopted, there has been a decrease in the range observed, partly because true negotiations have become more infrequent. Only five of the eight generic strategies observed by $\mathrm{BFB}$ are found by $\mathrm{BFH}$ : assertiveness (AP stating their position firmly at the outset); sanction (audit qualification threat); reason (CFO or AP using evidence to support their argument); coalescing (ACC using the audit committee to secure agreement); and higher authority (usually an audit firm technical department). In the prevailing culture of compliance there was no evidence of ingratiation, conditions being attached to acceptance or bargaining strategies such as the reciprocity-based bargaining strategy found in the US environment. This latter finding is due to the strong UK enforcement regime, under which such reciprocity is likely to be identified by the inspection regime.

A comparison of the boundaries of the observed two-dimensional outcome domain is found in each study is particularly revealing. A stylised visual representation is offered in Figure 3. It is apparent that the overall size of the outcome domain has shrunk, especially in relation to the outcome quality dimension. Thus, changes in the interaction environment appear to have reduced the variability of outcomes, especially outcome quality.

[Figure 3 about here] 
Provided this small variation is around a high average outcome quality, this homogenising effect is desirable. In support of this situation is the absence of noncompliant/unacceptable outcomes in the later study (there were four such outcomes in BFB). However the negative side to this effect is that the 'crusader' AP type cannot thrive in the changed regulatory environment. Such individuals find it difficult to 'go beyond' the accounting and auditing standards as they are written, due to the perceived loss of the true and fair view principle in the IFRS accounting model. This finding supports the view that the more a system is rules-based, the higher the likelihood that professional judgment will be diminished in favour of compliance with rules (Bennett $e t$ al., 2006). Thus, while all outcomes were of high quality in the narrow sense of the concept, there was clear evidence that the parties did not view some outcomes as being of high quality in the broader sense which includes the true and fair view concept.

Regulatory changes have slightly reduced the scope for very difficult outcomes. This is partly because the enhanced role of the audit committee has produced a fairly standard and generally simpler interaction 'pattern'. The CFO and AP are expected to agree issues and present this agreed solution to the ACC. More rules-based accounting standards have limited the scope for disagreement. This is coupled with the more rigorous enforcement regime which introduces substantive goal congruency (compliance). The triad then present the agreed solution to the audit committee which, in turn, presents it to the main board. The scope for the involvement of other individual executive directors, a characteristic feature of difficult interactions in BFB, is effectively eliminated by the audit committee's enhanced role.

\section{SUMMARY AND CONCLUSIONS}

The BFH study summarised in the present paper conducts face-to-face interviews with the CFOs, APs and ACCs of nine listed UK companies to investigate the interactions taking place as the financial reporting outcomes (numbers and disclosures) are agreed. Across the nine cases, a total of 45 interactions are analysed in depth and the grounded theory developed by BFB is revised to reveal the impact of the changed regulatory setting. Many interaction issues related to IFRS standards which have introduced significant change, such as goodwill and intangibles, deferred taxation and presentation of primary 
statements. One third of all interactions were classed as negotiations, however, intense negotiations (involving disagreement and conflict) appear to have become less frequent since the BFB study.

The Enron scandal resulted in an intense period of re-regulation in many jurisdictions. There was a drive for transparency in the audit process and in financial reporting disclosure by the accounting profession and governments (Wade, 2007). Although accounting and auditing standard-setting is increasingly global (Cooper \& Robson, 2006; Humphrey et al., 2009), the BFH study highlights the importance of the nationally-operated enforcement regime in relation to financial reporting and auditing outcomes. This finding is consistent with the general view of Arnold and Sikka (2001) that nation states remain important players in the regulation of global business.

Interviewees generally did not believe that the introduction of IFRS had improved the quality of UK financial reporting, due to excessive complexity, high disclosure volume and dysfunctional outcomes which did not reflect the substance of transactions in relation to the business. IFRS was perceived as a rules-based system where compliance and box-ticking, along with process-driven judgments, have tended to replace judgments based on principles such as substance over form and the use, where necessary, of the true and fair view override. The FRRP was considered an effective monitoring and enforcement body. In relation to auditing, ISAs were viewed as being overly detailed and prescriptive, producing too much emphasis to formal documentation rather than audit judgment. Similarly, the AIU was considered by many to be excessively concerned with detail, documentation and compliance at the expense of judgment. However, the AIU was considered a strong enforcement body and audit partners in receipt of an adverse AIU report could suffer damage to their career prospects.

This changed UK regulatory environment led directly to: (i) changes in the key parties involved in interactions; (ii) changes to the objectives, roles and behaviours of these parties; and, consequently, (iii) changes to the interaction process and outcome attributes. The corporate governance changes relating to the role of the audit committee and the ACC have been largely responsible for shifting the predominant dynamic in financial reporting interactions from a dyad relationship between the $\mathrm{CFO}$ and the AP to a triad relationship where the ACC, as chair of main board sub-committee, has oversight 
and monitoring responsibility for the integrity of the financial statements and responsibility for aspects of the auditor appointment and remuneration and conduct. Both the CFO and AP are accountable to the ACC, who manages the audit committee which, in turn, reports to the main board. These three key parties shared a general objective to comply with the rules and the processes underpinning judgments in standards in order to keep out of trouble with the regulatory enforcement bodies, to protect both their own reputation and position and that of the company. ACCs (usually the most financially literate member of the AC) generally played a key role in managing the relationships within the triad and were engaged in the financial reporting process, acting as gatekeeper for the audit committee. CFOs and APs were keen to take an agreed position to the ACC so that there was no loss of face and damage to personal reputation. ACCs often informally took on the monitoring role that is formally assigned to the audit committee (informal processes were also identified in the UK by Turley and Zaman, 2007). The ACC wished to be kept informed of developments on a 'no surprises' principle, leaving the audit committee to play a more ceremonial role at the end of an interaction, 'reviewing' or 'approving' proposed solutions. This is consistent with Spira (1999) and Beasley et al. (2009).

These different behaviour patterns of the individual ACC compared to the full audit committee resonate with the findings of Gendron \& Bédard (2006). Neither the ACC nor the audit committee was keen to act as arbiter. Interactions were typified by problemsolving behaviours, rather than disagreement and confrontation, as all parties wanted to avoid being 'caught' by the stringent regulatory environment. Auditors were primarily concerned with compliance where there are clear rules in IFRS and process where there are judgments associated with valuations. The true and fair view principle was notably absent from the mind-set of auditors and other key parties (it simply did not feature in any of the interviews in the present study). The general tenor of the interview evidence was that APs now regard professional judgment as something to be regulated and verified through inspection systems, consistent with the findings of Gendron \& Bédard (2006) in the Canadian context.

The interaction process was, compared to BFB, considerably less complex and less varied, as interactions had fewer events, fewer stages, and fewer parties involved. In the revised grounded theory interaction model, local contextual factors (both micro and 
meso-level factors) were weak influences on the interaction. Features such as the quality of primary relationships, company circumstances, reporting style, audit partner type and company buyer type and personality differences, which had been an important influence have become peripheral. In terms of company buyer types, the ACCs and CFOs were all comfort-seekers, with CFOs employed in smaller listed companies also being resource-seekers. In terms of AP (seller) types - the 'safe pair of hands' has become standard. The categories impacting most directly on the core category related to the macro regulatory regime, both the standard-setting regime and, closest to the core category, the enforcement regime.

Certain negotiation strategies (e.g. ingratiation and reciprocity-based strategies) no longer featured in interactions, as these unacceptable strategies could have been exposed by the enforcement regime. In matters of compliance, APs generally stated their position firmly at the outset (an assertiveness strategy). The two commonly used strategies in matters of judgment were reason and appeal to a higher authority, specifically the audit firm technical department.

The considerable range in the quality (in both the narrow and broad sense) of financial reporting outcomes observed by BFB was greatly reduced. All the compliance issues were classified as compliant and all judgment outcomes were classified as acceptable in terms of compliance with the process of reaching the judgment. Quality (in the narrow sense) outcomes were achieved in all cases. However it was noted that some of the highest quality (in the broad sense) outcomes were no longer achievable as a consequence of the strong compliance culture and the loss of the true and fair view. The most significant influence on the quality of financial reporting was the regulatory framework. The degree of judgment required has diminished under the changed regulatory framework; moreover the judgement of individual audit engagement partners has become 'standardised' by referral from the AP to the firm's technical department, causing the influence of distinctive individual professional judgment to all but disappear. This power shift within the firms from APs to technical departments is consistent with the erosion of accounting jurisdiction that ensues from complexification identified in Smith-Lacroix et al. (2012). In their study, the shift towards fair value accounting has led to a concomitant shift in the exercise of expert valuation judgements from auditors to specialized valuers. These changes in the authority and levels of judgment exercised by 
APs may be viewed in terms of the construction by firms of controllability boundaries (Gendron \& Spira, 2009).

Crucially, under an effective enforcement regime, it is the quality of the standards and regulations being enforced that will determine the quality of the final outcomes. Our analysis indicates that the ease of outcome agreement was also strongly affected by the regulatory framework, in particular, the existence of accounting standards which are more rules-based and the enhanced role of the audit committee. As in the case of outcome quality, the impact was to reduce outcome variability. Rules generally made agreement easier, as did the intervention of the non-executive audit committee directors in the relationships between the traditional dyad parties and the other executive directors.

The BFH study summarised in the present paper offers important insights into the auditing and financial reporting outcomes that arise from the unique regulatory nexus formed by a de jure rules-based a set of (international) accounting standards; an apparently strong national financial reporting enforcement regime; and an apparently strong national auditing practices enforcement regime and a change in the role of the ACC. The danger with a strongly enforced rules-based system is that it creates a compliance culture where participants, even if they are uncomfortable with the outcomes, engage in box-ticking and flawed accounting standards flow directly through to flawed financial reporting outcomes (a simple garbage in-garbage out model). ${ }^{22}$

These insights have relevance not only to regulators in the UK, but also to global regulatory bodies and regulators in other countries. The findings provide valuable evidence on the costs, benefits and unintended consequences of regulatory change in financial reporting and auditing regulation, thereby informing the intense current policy debate (Buijink 2006, Schipper 2010). It is argued that the shift towards more rulesbased regulation which is strongly enforced promotes a 'rule-checking' mentality - a mentality also noted by Ball (2009).

More fundamentally, now that the US convergence project has stalled, consideration could be given to moving IFRS towards a more de facto principles-based set of standards. The interaction stories in our study revealed that the participants were arguing 
about whether the accounting treatment complied with the rules or not, rather than whether it was the 'right' outcome. Moreover, the participants were generally aware of this distinction - they identified several specific IFRSs that they viewed as being flawed but felt compelled to comply with the standard. This awareness was because the participants were generally experienced individuals who were familiar with the previous UK system which had been predicated on the true and fair view concept. In the previous BFB study, the true and fair view was used as the most basic principle in several interactions. The loss of this principle was lamented by participants in the more recent BFH study - e.g. one ACC commented: 'perhaps I'm old fashioned but, I do believe that truth and fairness is, should be, the overriding principle...it means that Enron can't happen' (BFH, p.254).

The stability (i.e. transient or permanent nature) of the model of interactions presented here is unclear. We are seeking to understand what is going on in a particular setting and so the 'model' is a general understanding with respect to that setting (time and place). The regulatory aspects of model are clearly subject to discontinuities that influence the particular field logic of the time and hence the behaviour of individual actors. It is, therefore, a dynamic model that requires periodic updating. Nevertheless, it is important to document and understand the consequences (desirable and undesirable; intended and unintended) of particular regulatory mixes.

The BFH study summarised in this paper indicates that the changed system arises from the detailed nature of auditing and accounting standards themselves which are backed up with enhanced post-Enron enforcement. The evidence suggests that the incentives and hence behaviour of key interaction participants have been affected in fundamental ways and reveals the dangers of a rules-based, compliance driven system. Although compliance and ease of resolution of interactions have improved, the outcomes have not necessarily improved in parallel - some have been a cause for concern and others have been economically damaging. ${ }^{23}$

Nine years after the first concerns were raised about whether the UK Companies Act's true and fair view exists under IFRS, tensions continue between the FRC and other interested parties about the use of the true and fair view. The FRC has issued counsel's opinions that IFRS adoption has not undermined the true and fair view (FRC, 2008b, FRC, 2011). However, the Local Authority Pension Fund Forum (LAPFF, 2013) 
presented a second opinion to the UK Parliamentary Commission on Banking Standards which gave a contrary view. This was then countered by a further opinion from the FRC (2013b). The matter is not yet concluded.

These early findings from evidence gathered in 2007-2008, before the banking crisis took hold presaged the devastating outcomes that can emerge from a garbage in-garbage out accounting and auditing regulatory model. IAS 39 allowed banks, apparently legitimately, to overstate asset values by complying with the mark to market rule and the incurred loan loss provisioning regime. The Bank of England Financial Stability Report (2012, pp.19-20) indicated that, under this imprudent accounting regime, UK bank assets could be overstated by as much as $£ 50 \mathrm{bn}$.

Subsequent Parliamentary Inquiries into the global financial crisis have highlighted loss of trust in audit and in financial reporting in the banking sector because there was no forewarning of the crisis. These reports have become well-publicised and hence widely recognised. The House of Commons Treasury Committee (2009) criticised the usefulness of auditors on the grounds that they followed the rules but missed the point (p.109). The House of Lords Economic Affairs Committee (2011) made similar criticisms ( $\$ 198$, p.51). Debate and change designed to respond to the problems created is ongoing. Little change to the UK accounting, auditing and governance regime has been achieved to date, largely because the UK has limited control over the International Standards concerned.

As a result of the banking crisis, the UK auditing profession and EU legislators are engaging in various initiatives in an effort to restore trust in the profession which is viewed by many as having been seriously undermined. A recent influential UK report on restoring trust in audit commissioned by the profession has alluded to the dangers of a garbage in-garbage out regulatory model. This report, written in partnership by the RSA (Royal Society for the encouragement of Arts, Manufactures and Commerce) and AuditFutures (a thought-leadership partnership between ICAEW and the FRC-supported Finance Innovation Lab), observes that, 'It is one thing to believe in the accuracy of a financial statement audit, but it is another thing to believe in its utility...Regulators review the 'quality' of audits on a regular basis, but little has been done to construct models of quality that take account of the outcomes for the audited business' (pp.13-14). 
The same report (p. 15) also criticises the profession for defending the criticism of the 'dog that didn't bark' during the financial crisis by stating that it followed the rules laid down for it. On the accounting front, the European Parliament is reported to be questioning the transparency and governance of the IASB (Armitstead, 2014).

As part of the restoring trust initiative, the UK Audit Quality Forum, which meets quarterly, is currently debating the importance of reliability in accounts. In November 2013, a leading investor (Audit Quality Forum, 2013) set out his expectations of accounting to restore trust. He believes financial reporting should be: true and fair; prudent; able to prevent management optimism; aimed at long term capital providers; support capital maintenance; report profits that are distributable to protect shareholders and creditors; and auditors should be sceptical. The achievement of this 'ideal' provides a significant challenge to regulators due to the highly political nature of accounting standard-setting (see, for example, Power, 2010).

There is much to learn and research from this study. Whereas a compliance-driven accounting and auditing regulatory model produces less non compliance and outcomes which are easier to achieve, it does not protect investors and stakeholders in companies against defective standards unless there is an override. In circumstances where major regulatory change emanating from different sources (some domestic and some international) is introduced over a short period of time, the unintended consequences can have significant implications and the change process can take an unacceptably long time where the source of the regulation is international. The BFH revised grounded theory model identifies the risks inherent such a model which subsequently manifested themselves in the banking crisis and contributed to loss of trust in audit and the accounting profession more widely.

Future researchers and regulators need to address what has appeared in the UK to be a toxic mix between domestic and international regulation and mechanisms for putting right in a timely manner failures inherent in a garbage in-garbage out model. 


\section{NOTES}

${ }^{1}$ Strictly, the 'client' is the company's shareholders; a more appropriate term would be 'auditor-auditee interactions', however this term is seldom used in the literature.

${ }^{2}$ Such models are generalizable only within a particular time and country setting.

${ }^{3}$ The book went on to win the AAA Deloitte/Wildman Medal in 2007.

${ }^{4}$ As the UK Corporate Governance Code was known as the Combined Code for Corporate Governance at the time this study was carried out, we have used term Combined Code throughout.

${ }^{5}$ The FRRP has powers to apply to the court to force a company to restate its accounts if the directors refuse to do so voluntarily.

${ }^{6}$ The AIU was renamed the Audit Quality Review (AQR) team in 2012. For the purposes of this paper, we refer to the AQR team as the AIU throughout, as this was the name that applied at the time the data was collected.

${ }^{7}$ Neither the 2008 nor the 2010 revisions to the Corporate Governance Code (FRC 2008, 2010) materially changed the requirements for audit committees in relation to financial reporting in comparison with 2007. Changes introduced in the aftermath of the global financial crisis into the 2012 revision require companies (for accounting periods beginning on or after 1 October 2012) to include in a separate section of the annual report a description of 'the significant issues that [the audit committee] considered in relation to the financial statements, and how these issues were addressed (FRC 2012, para. C.3.8).

${ }^{8}$ These reforms were introduced under UK law and through the Department of Trade and Industry (DTI), now the Department of Business Innovation and Skills (BIS))

${ }^{9}$ Following the reform of the FRC, the Codes and Standards Committee takes responsibility for Audit and Assurance Council and Accounting Council, while the Monitoring Committee oversees the FRRP and the Audit Quality Review Team (formerly the AIU). For a description of the current FRC structure, see http://frc.org.uk/About-the-FRC/FRC-structure.aspx. We have no a priori reason to expect that these organisational changes would affect interaction behaviour.

${ }^{10}$ UK GAAP remains an option for other companies not covered by the Regulation, including subsidiaries of listed companies).

${ }^{11}$ Articles 2 (3-5) of directive 78/660/EEC state that: The annual accounts shall give a true and fair view of the company's assets, liabilities, financial position and profit or loss. Where the application of the provisions of this Directive would not be sufficient to give a true and fair view within the meaning of paragraph 3, additional information must be given. Where in exceptional cases the application of a provision of this Directive is incompatible with the obligation laid down in paragraph 3, that provision must be departed from in order to give a true and fair view within the meaning of paragraph 3 . Any such departure must be disclosed in the notes on the accounts together with an explanation of the reasons for it and a statement of its effect on the assets, liabilities, financial position and profit or loss. The Member States may define the exceptional cases in question and lay down the relevant special rules.

${ }^{12}$ The 'major' audit firms are those that audit more than ten listed UK companies or major public interest entities. There are currently nine such firms, including the Big Four. These firms are subject to a review of selected individual audits as well as the firm's policies and procedures. Compliance with the requirements of relevant standards and other aspects of the regulatory framework for auditing is assessed. For a detailed description, see http://www.frc.org.uk/Our-Work/Conduct/Audit-Quality-Review.aspx.

${ }^{13}$ ISAs became mandatory for all UK audits from December 2005 year ends onwards.

${ }^{14}$ Under the 2003 EU Accounts Modernization Directive, companies were required to produce a Business Review that disclosed information material to understanding the development, performance and position of the company, and the principal risks and uncertainties facing it. This narrative reporting regulation is comparable to the MD\&A in the US, Canada and Australia. The term used by the IASB is Management Commentary.

${ }^{15}$ Financial instruments (IAS 39) generally featured just outside the top ten discussion and negotiation issues.

${ }^{16}$ Archival AC research studies treat AC processes as a black box. In a review of such studies, Carcello et al. (2011) conclude that 'generally speaking, 'good' audit committee and board characteristics are associated with measures of 'good' accounting and auditing and with more effective internal controls' (p.3).

${ }^{17}$ We also obtained permission from the heads of audit of the firms involved to interview their partners and disclose we had permission. Heads of audit were not told by us which partners or clients were involved and it was left to the individual partners to choose whether to disclose their involvement.

${ }^{18}$ In fact, no company refused access. In a tenth company we interviewed the ACC but he did not want the CFO contacted so the case was not developed further.

${ }^{19}$ For a detailed description of the analytical process, see Beattie et al. (2001, p.254). 
${ }^{20}$ Some leading qualitative researchers go so far as to view it as 'impossible and illogical' to ignore the prior literature (e.g. Suddaby, 2006, p.634).

${ }^{21}$ It is likely that the high level can be partly attributed to the (then) recent implementation of IFRS.

${ }^{22}$ The phrase 'garbage in-garbage out' is a programming term that refers to programming code that contains an error and consequently produces incorrect/unintended actions. When applied to a regulatory context, 'garbage in' refers to those aspects of the IFRS system that are viewed as somehow 'wrong', while 'garbage out' refers to the resultant dysfunctional outcomes under a regime of strong enforcement that engenders a compliance culture.

${ }^{23}$ An example of economic damage is identified in the Bank of England financial stability report (2012), whereby the requirements of IAS 39 in relation to loan loss provisioning led to banks overstating their asset values. 


\section{REFERENCES}

Accounting Onion (2008), IFRS chaos in France. March. Accounting Onion. Available at: http://accountingonion.typepad.com/theaccountingonion/2008/03/socit-gnrale-a.html (Visited 9 April 2014).

APB (2004a), International Standards on Auditing (UK and Ireland), London: Auditing Practices Board.

APB (2004b), ISA (UK and Ireland) 260. Communication of audit matters with those charged with governance, International Standard on Auditing (UK and Ireland) 260, London: Auditing Practices Board.

APB (2004c), Ethical Standards 1-5, London: Auditing Practices Board.

Armitstead, L. (2014), IFRS could be stripped of accountancy watchdog role. 15 March. Telegraph. Available at: http://www.telegraph.co.uk/journalists/louisearmitstead/10700745/IFRS-could-be-stripped-of-accountancy-watchdog-role.html (Visited 28 April 2014).

Arnold, P.J. \& Sikka, P., (2001), 'Globalization and the state-profession relationship: the case of the Bank of Credit and Commerce International', Accounting, Organizations and Society, Vol. 26, No. 6, pp. 475-499.

ASB (1993), Operating and Financial Review, London: Accounting Standards Board.

ASB (2003), Operating and Financial Review, London: Accounting Standards Board.

ASB (2006), Reporting Statement: Operating and Financial Review, London: Accounting Standards Board Available from: http://www.frc.org.uk/OurWork/Publications/ASB/UITF-Abstract-24-Accounting-for-start-up-costs/ReportingStatement-Operating-and-Financial-Review.aspx [Accessed 16 July 2013].

Audit Inspection Unit (AIU) (2012), Audit Quality Inspections: Annual Report 2011/12, London: FRC. Available at: http://www.frc.org.uk/Our-Work/Publications/AIU/AuditQuality-Inspections-Annual-Report-2011-12.aspx, visited 30 ${ }^{\text {th }}$ July 2013.

Audit Quality Forum (2013), Can you rely on audited accounts? - A forum to identify improvements, Webcast (October 2013) Section 3. Available at: http://www.icaew.com/en/technical/audit-and-assurance/audit-quality-forum-aqf/aqfwebcast (visited 29 April 2014).

Ball, R. (2009), 'Market and political/regulatory perspectives on the recent accounting scandals', Journal of Accounting Research, Vol. 47, No. 2, pp. 277-323.

Bank of England (2012), Financial Stability Report. November. Bank of England. Available at: http://www.bankofengland.co.uk/publications/Pages/fsr/2012/fsr32.aspx (visited 19 June 2014). 
Beasley, M.S., Carcello, J.V., Hermanson, D.R. \& Neal, T.L. (2009), 'The audit committee oversight process', Contemporary Accounting Research, Vol. 26, No.1, pp. 65-122.

Beattie,V.A. \& Fearnley, S. (1998), What Companies Want (and Don't Want) From their Auditors, London: Institute of Chartered Accountants in England and Wales.

Beattie, V. A, Fearnley, S. \& Brandt, R. (2000), 'Behind the audit report: A descriptive study of discussion and negotiation between auditors and directors', International Journal of Auditing, Vol. 4, No. 2, pp. 177-202.

Beattie, V.A., Fearnley, S. \& Brandt, R. (2001), Behind Closed Doors: What Company Audit is Really About, Basingstoke: Palgrave.

Beattie, V., Fearnley, S. \& Brandt, R. (2004), 'A grounded theory model of auditor-client negotiations', International Journal of Auditing, Vol.8, No.1, pp. 1-19.

Beattie, V., Fearnley, S. \& Hines, A. (2008a), 'Does IFRS undermine UK reporting integrity?', Accountancy, December, pp. 56-57.

Beattie, V., Fearnley, S. \& Hines, T. (2008b), Auditor/Company Interactions in the 2007 UK Regulatory Environment: Discussion and Negotiation on Financial Statement Issues Reported by Finance Directors, Audit Committee Chairs and Audit Engagement Partners, Briefing. London: Institute of Chartered Accountants in England and Wales. Available at: http://www.icaew.com/ /media/Files/Technical/Research-andacademics/publications-and-projects/audit-and-assurance-publications/briefingauditor-company-interactions-in-the-2007-UK-regulatory-environment.pdf (visited 31st July 2013).

Beattie, V., Fearnley, S. \& Hines, A. (2009a), 'The accounting standards debate: the academics.' Finance Director Europe, Vol 2, pp. 16-17.

Beattie, V., Fearnley, S. \& Hines, T. (2009b), The Impact of Changes to the Non-audit Services Regime on Finance Directors, Audit Committee Chairs and Audit Partners of UK Listed Companies, Briefing. London: Institute of Chartered Accountants in England and Wales, Available at: http://www.icaew.com/ /media/Files/Technical/Researchand-academics/publications-and-projects/audit-and-assurance-publications/briefingthe-impact-of-the-changes-to-the-non-audit-services.pdf (visited 31st July 2013).

Beattie, V., Fearnley, S. \& Hines, T. (2011), Reaching Key Financial Reporting Decisions: How UK Directors and Auditors Interact, Chichester: John Wiley \& Sons.

Beattie, V., Fearnley, S. \& Hines, T. (2013), 'Perceptions of factors affecting audit quality in the post-SOX UK regulatory environment', Accounting and Business Research, Vol. 43, No. 1, pp. 56-81.

Beattie, V., Fearnley, S. \& Hines, T. (2014), 'Boundary spanning and gatekeeping roles of UK audit committees', Accounting and Business Research, Vol. 44, No. 3, pp. 315343. 
Bédard, J. \& Gendron, Y. (2010), 'Strengthening the financial reporting system: can audit committees deliver?', International Journal of Auditing, Vol. 14, No. 2, pp.174-210.

Bennett, B., Bradbury, M. \& Prangnell, H. (2006), 'Rules, principles and judgments in accounting standards', Abacus, Vol. 42, No. 2, pp. 189-204.

Brown, S.M. (1992), 'Cognitive mapping and repertory grids for qualitative survey research: some comparative observations', Journal of Management Studies, Vol. 29, No. 3, pp. 287-307.

Brown, P., Preiato, J. \& Tarca, A. (2014), 'Measuring country differences in enforcement of accounting standards: an audit and enforcement proxy', Journal of Business Finance and Accounting, Vol. 41, Nos. (1) \& (2), pp.1-52.

Buddery, P., Frank, S. \& Martinoff, M. (2014), Enlightening Professions? A Vision for Audit and a Better Society. London: ICAEW. Available at: http://auditfutures.org/EnlighteningProfessions.pdf (visited 28 April 2014).

Buijink, W. (2006), 'Evidence-based financial reporting regulation', Abacus, Vol.42, No. 3/4, pp. 296-301.

Bush, T. (2009), 'Is the view true and fair?', Accountancy, May, p.20.

Cadbury Report (1992) Report of the Committee on the Financial Aspects of Corporate Governance,. London: Gee and Co.

Canning, M. \& O'Dwyer, B. (2013), The dynamics of a regulatory space realignment: strategic responses in a local context', Accounting, Organizations and Society, Vol. 38, No. 3, pp. 169-194.

Carcello, J.V., Hermanson, D.R. \& Ye, Z. (2011), 'Corporate governance research in accounting and auditing: insights, practice implications, and future research directions', Auditing: A Journal of Practice and Theory, Vol.30, No. 3, pp. 1-31.

Coffee, J.C. (2006), Gatekeepers: The Professions and Corporate Governance, Oxford, UK: Oxford University Press.

Cohen, J., Gaynor, L.M., Krishnamoorthy, G. \& Wright, A.M. (2007), 'Auditor communications with the audit committee and the board of directors: Policy recommendations and opportunities for future research', Accounting Horizons. Vol. 21, No. 2, pp. 165-187.

Cohen, J., Krishnamoorthy, G. \& Wright, A. M. (2008), 'Form versus substance: The implications for auditing practice and research of alternative perspectives on corporate governance', Auditing: A Journal of Practice and Theory, Vol. 27, No. 2, pp. 181-198.

Cohen, J., Krishnamoorthy, G. \& Wright, A. (2010), 'Corporate governance in the post Sarbanes-Oxley era: Auditors' experiences', Contemporary Accounting Research, Vol. 27, No. 3, pp. 751-786. 
Companies Act (2006), The Stationery Office: London.

Competition Commission (2013), Statutory Audit Services for Large Companies Market Investigation: A Report on the Provision of Statutory Audit Services to Large Companies in the UK. Available from: http://www.competitioncommission.org.uk/assets/competitioncommission/docs/2011/statutory-auditservices/131016_final_report.pdf [Accessed 4 December 2013].

Cooper, D.J. \& Robson, K. (2006), 'Accounting, professions and regulation: locating the sites of professionalization', Accounting, Organizations and Society, Vol. 31, No. 4-5, pp. 415-444.

Corbin, J. \& Strauss, A. (2008). Basics of Qualitative Research: Techniques and Procedures for Developing Grounded Theory, (3rd edition) London: Sage Publications.

DeZoort, F.T., Hermanson, D.R. \& Houston, R.W. (2008), 'Audit committee member support for proposed audit adjustments: Pre-SOX versus post-SOX judgments’, Auditing: A Journal of Practice and Theory, Vol. 27, No. 1, pp. 85-105.

European Commission (EC) (2011), Proposal for a Regulation of the European Parliament and of the Council: on specific requirements regarding statutory audit of public interest entities, Brussels. COM (2011) 779/3. 2011/0359(COD). European Commission: Brussels.

European Commission (EC) (2013), Commissioner Michel Barnier welcomes provisional agreement in trilogue on the reform of the audit sector, MEMO/13/1171 17/12/2013 European Commission: Brussels. Available at: http://europa.eu/rapid/pressrelease_MEMO-13-1171_en.htm?locale=en (visited 19 March 2014).

EFRAG/ANC/FRC (2012), Towards a Disclosure Framework for the Notes, Discussion Paper. Available at: http://www.efrag.org/Front/n2-972/Discussion-Paper--Towards-a-Disclosure-Framework-for-the-Notes.aspx (visited 1 July 2013).

European Union (2002), Regulation (EC) 1606/2002 of the European Parliament and of the Council on the Application of International Accounting Standards, Brussels: European Union.

Evans, L. (2003), 'The true and fair view and the 'fair' presentation override of IAS 1', Accounting and Business Research, Vol. 33, No. 4, pp. 311-325.

FASB (2013), Disclosure Framework Available at http://www.fasb.org/cs/ContentServer?pagename=FASB\%2FFASBContent_C\%2FP rojectUpdatePage\&cid=1176156344894, (visited 1 July 2013).

Fearnley, S., Hines, T., Brandt, R. \& McBride, K. (2002), 'The impact of the Financial Reporting Review Panel on aspects of the independence of auditors and their attitudes to compliance in the UK', British Accounting Review, Vol.34, No. 2, pp. 109-139. 
FRC (1998), The Combined Code on Corporate Governance, London: Financial Reporting Council

FRC (2003), The Combined Code on Corporate Governance, London: Financial Reporting Council.

FRC (2005), True and Fair View, London: Financial Reporting Council.

FRC (2006a), The Combined Code on Corporate Governance, London: Financial Reporting Council.

FRC (2006b), The UK Approach to Corporate Governance, London: Financial Reporting Council.

FRC (2008a), The True and Fair Requirement Revisited, London: Financial Reporting Council.

FRC (2008b), The Combined Code on Corporate Governance, London: Financial Reporting Council.

FRC (2010), The UK Corporate Governance Code, London: Financial Reporting Council.

FRC (2011), True and Fair, London: Financial Reporting Council.

FRC (2012), The UK Corporate Governance Code London: Financial Reporting Council. Available from: http://frc.org.uk/Our-Work/Publications/Corporate-Governance/UKCorporate-Governance-Code-September-2012.aspx [Accessed 24 May 2013].

FRC (2013a), Former FRC Structure, Available at: http://frc.org.uk/FRCDocuments/FRC/Organisation-Chart.aspx (visited 1 July 2013).

FRC (2013b), International Accounting Standards and the True and Fair View, London: Financial Reporting Council.

Gendron, Y. \& Bédard, J. (2006), 'On the constitution of audit committee effectiveness', Accounting, Organizations and Society, Vol. 31, No. 3, pp. 211-239.

Gendron, Y. \& Spira, L. (2009), 'What went wrong? The downfall of Arthur Andersen and the construction of controllability boundaries surrounding financial auditing', Contemporary Accounting Research, Vol. 26, No. 4, pp. 987-1027.

Gibbins, M., Salterio, S. \& Webb, A. (2001), 'Evidence about auditor-client management negotiation concerning client's financial reporting', Journal of Accounting Research, Vol. 39, No. 3, December, pp. 535-563.

Gibbins, M., McCracken, S.A. \& Salterio, S.E. (2005), 'Negotiations over accounting issues: the congruency of audit partner and chief financial officer recalls', Auditing: A Journal of Practice and Theory, Vol. 24 (Supplement), pp. 171-193. 
Gibbins, M, McCracken, S.A. \& Salterio, S.E. (2007), 'The Chief Financial Officer's perspective on auditor-client negotiations', Contemporary Accounting Research, Vol. 24, No. 2, pp. 387-422.

Glaser, B.G. \& Strauss, A. (1967), Discovery of Grounded Theory: Strategies for Qualitative Research. Sociology Press.

Greenwood, R., Suddaby, R. \& Hinings, C.R. (2002), 'Theorizing change: the role of professional associations in the transformation of institutionalized fields', Academy of Management Journal, Vol.45, No. 1, pp. 58-80.

Hampel Report (1998), Committee on Corporate Governance - Final Report. London: Gee and Co.

Hansen, C.D. \& Kahnweiler, W.M. (1993), 'Storytelling: an instrument for understanding the dynamics of corporate relationships', Human Relations, Vol. 46, No. 12, pp.1391-409.

Hatfield, R.C., Agoglia, C.P. \& Sanchez, M.H. (2008), 'Client characteristics and the negotiation tactics of auditors: implications for financial reporting', Journal of Accounting Research, Vol. 46, No. 5, pp. 1183-1207.

Hoogendoorn, M., (2006), 'International accounting regulation and IFRS implementation in Europe and beyond - experiences with first-time adoption in Europe', Accounting in Europe, Vol. 3, No. 1, pp. 23-26.

House of Commons Treasury Committee (2009), Banking Crisis: Reforming Corporate Governance and Pay in the City 2008-9: Ninth Report of Session 2008-09. Available at:

http://www.publications.parliament.uk/pa/cm200809/cmselect/cmtreasy/519/519.pdf (visited 9 April 2014).

House of Lords (2011), Auditors: Market Concentration and Their Role. Select Committee on Economic Affairs, Volume 1: Report, London: The Stationery Office Limited.

House of Lords (2012), Auditors: EAC Report. http://www.publications.parliament.uk/pa/ld201212/ldhansrd/text/120314gc0001.htm\#12031474000039 [Accessed 22 March 2012].

House of Lords / House of Commons (2013), 'Changing Banking for Good - Report of the Parliamentary Commission on Banking Standards', HL Paper 27-1 HC 175-1.

Humphrey, C. Loft, A. \& Woods, M. (2009), 'The global audit profession and the international financial architecture: understanding regulatory relationships at a time of financial crisis', Accounting, Organizations and Society, Vol. 34, No. 6-7, pp. 810-825.

International Accounting Standards Board (2003), International Accounting Standard 1, Presentation of Financial Statements, London: International Accounting Standards Board. 
IASB (2013a), Discussion Forum - Financial Statement Disclosure, Feedback Statement. Available at: http://www.iasb.co.uk/ (visited 1 July 2013).

IASB (2013b), Update by the IASB and FASB, Available at: http://www.ifrs.org/Use-aroundthe-world/Global-convergence/Convergence-with-US-GAAP/Documents/IASB-

FASB-G20-Update-February-2013.pdf (visited 1 July 2013).

IASC Foundation (2007), Annual Report. Available at: http://www.ifrs.org/Theorganisation/Governance-and-accountability/Annualreports/Documents/IASCF_annual_report_2007.pdf (visited 9 April 2014).

ICAEW (2007), EU Implementation of IFRS and the Fair Value Directive, London: Institute of Chartered Accountants in England and Wales.

IIRC (2013), Consultation Draft of the International Integrated Reporting Framework, International Integrated Reporting Council. Available at: http://www.theiirc.org/consultationdraft2013/ [Accessed 16 July 2013].

Kelle, U. (2005), 'Emergence' vs. 'forcing' of empirical data? A crucial problem of 'grounded theory' reconsidered', Forum: Qualitative Social Research, Vol. 6, No. 2, Available at http://www.qualitative-research.net/index.php/fqs/article/view/467, visited $7^{\text {th }}$ Sept 2010.

LAPFF (2013), Leading Counsel Confirms Substantial Legal Problems with IFRS, Local Authority Pension Fund Forum. Available at: http://www.lapfforum.org/TTx2/news/leading-counsel-confirms-substantial-legalproblems-with-ifrs, visited $30^{\text {th }}$ July 3013.

Lennox, C. (2009), 'The changing regulatory landscape: editorial', International journal of auditing, Vol.13, No. 2, pp.79-85.

Lever, K. (2005), 'Objections to IFRS are not transition pains, they are serious issues', Financial Times . Letter 11 October. Available at: http://www.ft.com/cms/s/0/f889c618-39f2-11da-806e-

00000e2511c8.html\#axzz2y2eVKmgx (visited 9 April 2014)

Lincoln, Y.S. \& Guba, E.G. (1985), Naturalistic Inquiry, Volume 75 Sage Focus, Thousand Oaks, CA: Sage Publications.

Livne, G. \& McNichols, M. (2009), 'An empirical investigation of the true and fair override in the United Kingdom', Journal of Business Finance and Accounting, Vol. 36, No. 1\&2, pp. 1-30.

Malsch, B. \& Gendron, Y. (2011), 'Reining in auditors: on the dynamics of power surrounding an 'innovation' in the regulatory space', Accounting, Organizations and Society, Vol. 36, No. 7, pp. 456-476. 
McCracken, S., Salterio, S. \& Gibbins, M. (2008), 'Auditor-client management relationships and roles in negotiating financial reporting', Accounting, Organizations and Society, Vol. 33, No. 4-5, pp. 362-383.

Menkel-Meadow, C. (2009), 'Chronicling the complexification of negotiation theory and practice', Negotiation Journal, Vol.25, No.4, pp. 415-429.

Nelson, M.W. (2005). 'A review of experimental and archival conflicts-of-interest research in auditing' in Moore, D.A. Cain, D.M. Loewenstein, G. and Bazerman, M.H. (Eds.), Conflicts of Interest: Problems and Solutions in Law, Medicine, and Organizational Settings. Cambridge: Cambridge University Press.

Nelson, M. \& Tan, H-T. (2005), 'Judgment and decision making research in auditing: A task, person, and interpersonal interaction perspective', Auditing: A Journal of Practice and Theory, Vol. 24 (Supplement), pp. 41-71.

Nobes, C. (1993), 'The true and fair view requirement: impact on and of the Fourth Directive', Accounting and Business Research, Vol. 24, No. 93, pp. 415-427.

Nobes, C. (2009), 'The importance of being fair: an analysis of IFRS regulation and practice - a comment', Accounting and Business Research, Vol. 39, No. 4, pp. 415-427.

Norris, F. (2008), 'Loophole lets bank rewrite the calendar, New York Times, March 7. Available at: http://www.nytimes.com/2008/03/07/business/07norris.html?_r=1\&adxnnl=1\&adxnnlx =1384362803-msy9buwdyguw4o5jdqavwa\& (Visited 9 April 2014).

Penman. S.H. (2007), 'Financial reporting quality: is fair value a plus or a minus?' Accounting and Business Research, Special Issue: International Accounting Policy Forum, Vol. 37, No.3, pp. 33-44.

Pomeroy, B (2010), 'Audit committee member investigation of significant accounting decisions', Auditing: A Journal of Practice \& Theory, Vol. 29, No.1, pp. 173-205.

Power, M. (2010), 'Fair value accounting, financial economics and the transformation of reliability', Accounting and Business Research, Vol. 40, No. 3, pp. 197-210.

Richards, I. (2005), 'Undermining the statutory audit', June. Department of Trade and Industry. Available at: http://webarchive.nationalarchives.gov.uk/+/http://www.dti.gov.uk/cld/pdfs/morley.pdf (Visited 30 April 2014).

Salleh, Z. and Stewart, J. (2012), 'The role of the audit committee in resolving auditor-client disagreements: A Malaysian study', Accounting, Auditing and Accountability Journal, Vol. 25, No. 8, pp. 1340-1372.

Salterio, S.E. (2012), 'Fifteen years in the trenches: auditor-client negotiations exposed and explored', Accounting and Finance, Vol.52 (Supplement), pp. 233-286. 
Sanchez, M.H., Agoglia, C.P. \& Hatfield, R.C. (2007). 'The effect of auditors' use of a reciprocity-based strategy on auditor-client negotiations', The Accounting Review, Vol. 82, No. 1, pp. 241-263.

Sarbanes-Oxley Act, (2002), Available from: http://taft.law.uc.edu/CCL/SOact/soact.pdf. [Accessed 3 October 2011].

Schipper, K. (2005), 'The introduction of International Accounting Standards in Europe: implications for international convergence', European Accounting Review, Vol. 14, No. 1, pp. 101-126.

Schipper, K. (2010), 'How can we measure the costs and benefits of changes in financial reporting standards?', Accounting and Business Research, Vol. 40, No. 3, pp. 309327.

Smith Committee (2003), Audit Committee Combined Code Guidance, London: Financial Reporting Council.

Smith-Lacroix, J.-H., Durocher, S. \& Gendron, Y. (2012), 'The erosion of jurisdiction: auditing in a market value accounting regime', Critical Perspectives on Accounting, Vol. 23, No. 1, pp. 36-53.

Spira, L. (1999) 'Ceremonies of governance: perspectives on the role of the audit committee', Journal of Management and Governance, Vol. 3, No. 3, pp. 231-260.

Suddaby, R. (2006), 'From the editors: what grounded theory is not', Academy of Management Journal, Vol. 49, No. 4, pp. 633-642.

Suddaby, R., Cooper, D.J. \& Greenwood, R. (2007), 'Transnational regulation of professional services: governance dynamics of field level organizational change, Accounting, Organizations and Society, Vol. 32, No. 4-5, pp. 333-362.

Suddaby, R., Gendron, Y. \& Lam, H. (2009), 'The organizational context of professionalism in accounting', Accounting, Organizations and Society, Vol. 34, No. 3-4, pp. 409427.

Turley, S. \& Zaman, M. (2007), 'Audit committee effectiveness: processes and behavioural effects', Accounting, Auditing and Accountability Journal, Vol. 20, No. 5, 765-768.

Wade, R. (2007), 'A new global financial architecture?', New Left Review, Vol. 46 (JulyAugust), pp. 113-129.

Walton, P. (1997), 'The true and fair view and the drafting of the Fourth Directive', European Accounting Review, Vol. 6, No. 4, pp.721-730.

Yin, R.K. (2008), Case Study Research: Design and Methods, (4 ${ }^{\text {th }}$ edition) Newbury Park, CA: Sage Publications. 


\section{Appendix 1: List of abbreviations}

ACC Audit Committee Chair

AP

AIU

APB

ASB

BFB

$\mathrm{BFH}$

CEO

CFO

EFRAG

EU

FASB

FRC

FRRP

IAS

IAASB

ICAEW

IFAC

IFRS

IIRC

ISA

POB

SOX
Audit Engagement Partner

Audit Inspection Unit

Auditing Practices Board

Accounting Standards Board

Beattie, V.A., Fearnley, S. \& Brandt, R. (2001), Behind Closed Doors: What Company

Audit is Really About, Basingstoke: Palgrave.

Beattie, V. A., Fearnley, S. \& Hines, T. (2011), Reaching Key Financial Reporting

Decisions: How UK Directors and Auditors Interact, Chichester: John Wiley \& Sons.

Chief Executive Officer

Chief Financial Officer

European Financial Reporting Advisory Group

European Union

Financial Accounting Standards Board

Financial Reporting Council

Financial Reporting Review Panel

International Accounting Standard

International Auditing and Assurance Standards Board

Institute of Chartered Accountants in England and Wales

International Federation of Accountants

International Financial Reporting Standard

International Integrated Reporting Council

International Standard on Auditing

Public Oversight Board

Sarbanes-Oxley Act 


\section{Appendix 2: Definition of key terms}

Discussion: matters raised by one or more participants and considered in speech or writing

Negotiation: the process of reconciling conflicting views advanced in discussion, by concessions by one, two or all participants

Judgment decision: where no rule exists, e.g. valuation decisions

Compliance decision: where a clear rule exists

Company buyer types: a taxonomy inductively derived by Beattie \& Fearnley (1998) comprising:

Comfort-seekers: sees significant value in audit and wants assurance that controls are operating effectively and the financial statements are of high quality

Resource-seekers: sees significant value in audit, wants technical financial reporting advice, business ideas and non-audit services (types of advice and service no longer permitted under ethical standards for auditors)

Status-seekers: see little value in audit but wishes to gain credibility and reputation by associating with an audit firm of high status

Grudgers: see little value in audit and seeks to minimise audit fee

Audit partner seller types: a taxonomy inductively derived by Beattie et al. (2001) comprising:

Crusader: has extremely high professional and personal integrity and is fully prepared to escalate an issue

Safe hands: exhibits high professional integrity, identifies closely with the client and, and is prepared to escalate an issue

Accommodator: has moderate professional integrity and will knowingly bend the rules under pressure

Truster: has moderate professional integrity and may, unknowingly, permit rules to be bent because (s)he is not sufficiently sceptical

Quality of outcome: In evaluating individual outcomes, 'quality' is defined narrowly in terms of the applicable regulatory framework, without making any evaluation of that framework. In the case of compliance issues, quality may be equated to compliance. Where an outcome is a matter of judgment it is not possible to evaluate the quality of the judgment but is it is possible to consider it in terms of compliance with the process of reaching the judgment. In evaluating outcomes in general, however, the broader intrinsic quality is considered, i.e. whether the outcome shows a true and fair view. This is an overriding provision in UK company law to ensure the integrity of financial statements.

Ease of agreement: captures issues such as: number of parties involved, number of interaction stages, and use of strategies that undermine ongoing relationships. 
Table 1: Summary of UK Regulatory Changes - 1997 to 2007

\begin{tabular}{|c|c|c|c|}
\hline Regulation & 1997 & 2007 & Comment \\
\hline $\begin{array}{l}\text { Applicable accounting } \\
\text { standards for group } \\
\text { accounts of listed } \\
\text { companies }\end{array}$ & UK GAAP & IFRS & More rules-based \\
\hline Overriding principle & True and fair view & $\begin{array}{l}\text { Present fairly in } \\
\text { accordance with } \\
\text { applicable accounting } \\
\text { framework }\end{array}$ & $\begin{array}{l}\text { Reduction in } \\
\text { professional } \\
\text { judgment }\end{array}$ \\
\hline $\begin{array}{l}\text { Financial Accounting } \\
\text { enforcement body }\end{array}$ & FRRP & FRRP & Becomes proactive \\
\hline Auditing standards & UK auditing standards & ISAs (UK \& Ireland) & More rules-based \\
\hline $\begin{array}{l}\text { Auditing enforcement } \\
\text { body }\end{array}$ & $\begin{array}{l}\text { Peer review by } \\
\text { professional body }\end{array}$ & AIU & $\begin{array}{l}\text { Independent review; } \\
\text { results made public }\end{array}$ \\
\hline $\begin{array}{l}\text { Corporate governance } \\
\text { code }\end{array}$ & 1996 Combined Code & 2006 Combined Code & $\begin{array}{l}\text { Role of AC } \\
\text { extended; } \\
\text { communication } \\
\text { between AC and } \\
\text { external auditor } \\
\text { extended }\end{array}$ \\
\hline
\end{tabular}


Table 2: Descriptive data and analysis of nine case companies and 45 interactions

\begin{tabular}{|c|c|c|c|c|c|c|c|}
\hline \multirow{2}{*}{$\begin{array}{l}\text { Case } \\
\text { company } \\
\text { ID }\end{array}$} & \multirow{2}{*}{$\begin{array}{l}\text { Company } \\
\text { size/audit } \\
\text { firm type }\end{array}$} & \multirow[t]{2}{*}{ Interaction issue } & \multicolumn{3}{|c|}{ Interaction attributes } & \multicolumn{2}{|c|}{ Outcome attributes } \\
\hline & & & $\begin{array}{l}\text { Interaction } \\
\text { type }\end{array}$ & Issue type $^{1}$ & Decision type & $\begin{array}{l}\text { Quality of } \\
\text { outcome }\end{array}$ & $\begin{array}{l}\text { Ease of } \\
\text { agreement }\end{array}$ \\
\hline $\mathrm{S}$ & Large/B4 & $\begin{array}{l}\text { 1. Audit fees } \\
\text { 2. Cost treatment } \\
\text { 3. Re-organization costs } \\
\text { 4. Inventory provisions } \\
\text { 5. Dividends from subs } \\
\text { 6. Pension liabilities }\end{array}$ & $\begin{array}{l}\text { Negotiation } \\
\text { Negotiation } \\
\text { Negotiation } \\
\text { Negotiation } \\
\text { Discussion } \\
\text { Negotiation }\end{array}$ & $\begin{array}{l}\text { Audit } \\
\text { Measurement } \\
\text { Classification } \\
\text { Measurement } \\
\text { Classification } \\
\text { Measurement } \\
\end{array}$ & $\begin{array}{l}\text { n/a } \\
\text { Compliance/judgement } \\
\text { Judgement } \\
\text { Judgement } \\
\text { Compliance } \\
\text { Judgement }\end{array}$ & $\begin{array}{l}\text { n/a } \\
\text { Acceptable } \\
\text { Acceptable } \\
\text { Acceptable } \\
\text { Compliant } \\
\text { Acceptable }\end{array}$ & $\begin{array}{l}\text { Difficult } \\
\text { Difficult } \\
\text { Difficult } \\
\text { Slightly difficult } \\
\text { Easy } \\
\text { Slightly difficult }\end{array}$ \\
\hline $\mathrm{K}$ & Large/B4 & $\begin{array}{l}\text { 1. Intangibles val'n } \\
\text { 2. Impairment reviews } \\
\text { 3. Fin'l instruments - } \\
\quad \text { pref.shares } \\
\text { 4 Fin'l instruments - hedging } \\
\text { 5. Re-organisation costs } \\
\text { 6. Fraud and illegal acts }\end{array}$ & $\begin{array}{l}\text { Negotiation } \\
\text { Negotiation } \\
\text { Negotiation } \\
\text { Discussion } \\
\text { Discussion } \\
\text { Discussion }\end{array}$ & $\begin{array}{l}\text { Recog'n/Meas't } \\
\text { Meas't/Disc } \\
\text { Classification } \\
\text { Recog'n/Meas't } \\
\text { Classification } \\
\text { Audit }\end{array}$ & $\begin{array}{l}\text { Compliance/judgement } \\
\text { Judgement } \\
\text { Compliance } \\
\text { Compliance/judgement } \\
\text { Judgement } \\
\text { n/a }\end{array}$ & $\begin{array}{l}\text { Compliant } \\
\text { Acceptable } \\
\text { Compliant } \\
\text { Compliant } \\
\text { Acceptable } \\
\text { n/a }\end{array}$ & $\begin{array}{l}\text { Difficult } \\
\text { Difficult } \\
\text { Difficult } \\
\text { Easy } \\
\text { Easy } \\
\text { Easy }\end{array}$ \\
\hline$M$ & Large/B4 & $\begin{array}{l}\text { 1. Audit fee } \\
\text { 2. Complex transaction } \\
\text { 3. Business Review } \\
\text { 4. Fin' instruments - hedging } \\
\text { 5. Going concern } \\
\text { 6. Impairment of assets }\end{array}$ & $\begin{array}{l}\text { Negotiation } \\
\text { Negotiation } \\
\text { Discussion } \\
\text { Negotiation } \\
\text { Discussion } \\
\text { Discussion }\end{array}$ & $\begin{array}{l}\text { Audit } \\
\text { Recog'n/Meas't } \\
\text { Disclosure } \\
\text { Recog'n/Meas't } \\
\text { Fund'l principle } \\
\text { Measurement }\end{array}$ & $\begin{array}{l}\text { n/a } \\
\text { Judgement } \\
\text { Judgement } \\
\text { Compliance/judgement } \\
\text { Judgement } \\
\text { Judgement }\end{array}$ & $\begin{array}{l}\text { n/a } \\
\text { Acceptable } \\
\text { Acceptable } \\
\text { Compliant } \\
\text { Acceptable } \\
\text { Acceptable }\end{array}$ & $\begin{array}{l}\text { Difficult } \\
\text { Difficult } \\
\text { Easy } \\
\text { Difficult } \\
\text { Easy } \\
\text { Easy }\end{array}$ \\
\hline $\mathrm{F}$ & Small/B4 & $\begin{array}{l}\text { 1. Audit fees post tender } \\
\text { 2. Notional interest treatment } \\
\text { 3. Earnings per share } \\
\text { 4. Share based payments } \\
\text { 5. Treatment of tax credits } \\
\text { 6. Revenue recognition } \\
\text { 7. Intangibles val'n } \\
\text { 8. Segmental reporting } \\
\text { 9. Business Review }\end{array}$ & $\begin{array}{l}\text { Negotiation } \\
\text { Negotiation } \\
\text { Discussion } \\
\text { Negotiation } \\
\text { Negotiation } \\
\text { Discussion } \\
\text { Discussion } \\
\text { Discussion } \\
\text { Discussion }\end{array}$ & $\begin{array}{l}\text { Audit } \\
\text { Meas't/Disc } \\
\text { Disclosure } \\
\text { Recognition } \\
\text { Meas't/Disc } \\
\text { Recog'n/Meas't } \\
\text { Recog'n/Meas't } \\
\text { Disclosure } \\
\text { Disclosure }\end{array}$ & $\begin{array}{l}\mathrm{n} / \mathrm{a} \\
\text { Compliance/judgement } \\
\text { Compliance } \\
\text { Compliance } \\
\text { Compliance } \\
\text { Judgement } \\
\text { Compliance/judgement } \\
\text { Judgement } \\
\text { Judgement }\end{array}$ & $\begin{array}{l}\text { n/a } \\
\text { Compliant } \\
\text { Compliant } \\
\text { Compliant } \\
\text { Compliant } \\
\text { Gen. acceptable } \\
\text { Compliant } \\
\text { Acceptable } \\
\text { Acceptable }\end{array}$ & $\begin{array}{l}\text { Slightly difficult } \\
\text { Slightly difficult } \\
\text { Easy } \\
\text { Difficult } \\
\text { Slightly difficult } \\
\text { Easy } \\
\text { Easy } \\
\text { Easy } \\
\text { Easy }\end{array}$ \\
\hline $\mathrm{C}$ & $\begin{array}{l}\text { Small/non } \\
\text {-B4 }\end{array}$ & $\begin{array}{l}\text { 1. Identification of } \\
\text { intangibles on acq'n }\end{array}$ & Discussion & Recog'n/Meas't & Compliance/judgement & Compliant & Easy \\
\hline
\end{tabular}




\begin{tabular}{|c|c|c|c|c|c|c|c|}
\hline & & $\begin{array}{l}\text { 2. Impairment of goodwill } \\
\text { 3. Deferred tax asset } \\
\text { 4. Provision on inventories } \\
\text { 5. Business Review } \\
\text { 6. Misreporting in subsidiary }\end{array}$ & $\begin{array}{l}\text { Discussion } \\
\text { Discussion } \\
\text { Discussion } \\
\text { Discussion } \\
\text { Discussion }\end{array}$ & $\begin{array}{l}\text { Measurement } \\
\text { Measurement } \\
\text { Measurement } \\
\text { Disclosure } \\
\text { Meas't/Corp.Gov }\end{array}$ & $\begin{array}{l}\text { Judgement } \\
\text { Judgement } \\
\text { Judgement } \\
\text { Judgement } \\
\text { Judgement }\end{array}$ & $\begin{array}{l}\text { Acceptable } \\
\text { Acceptable } \\
\text { Acceptable } \\
\text { Acceptable } \\
\text { Acceptable }\end{array}$ & $\begin{array}{l}\text { Easy } \\
\text { Easy } \\
\text { Easy } \\
\text { Easy } \\
\text { Easy }\end{array}$ \\
\hline $\mathrm{P}$ & Large/B4 & $\begin{array}{l}\text { 1. Presentation of cash flow } \\
\text { statement } \\
\text { 2. Inventory valuation } \\
\text { 3. Contingent liabilities } \\
\text { 4. FV of lease on acq'n } \\
\text { 5. Re-organisation costs } \\
\text { 6. Segmental reporting } \\
\text { 7. Control weakness }\end{array}$ & $\begin{array}{l}\text { Negotiation } \\
\text { Discussion } \\
\text { Discussion } \\
\text { Discussion } \\
\text { Discussion } \\
\text { Discussion } \\
\text { Discussion }\end{array}$ & $\begin{array}{l}\text { Classification } \\
\text { Measurement } \\
\text { Disclosure } \\
\text { Measurement } \\
\text { Classification } \\
\text { Disclosure } \\
\text { Corp. Gov./Disc. }\end{array}$ & $\begin{array}{l}\text { Judgement } \\
\text { Judgement } \\
\text { Judgement } \\
\text { Judgement } \\
\text { Judgement } \\
\text { Judgement } \\
\text { Judgement }\end{array}$ & $\begin{array}{l}\text { Acceptable } \\
\text { Acceptable } \\
\text { Acceptable } \\
\text { Acceptable } \\
\text { Acceptable } \\
\text { Acceptable } \\
\text { Acceptable }\end{array}$ & $\begin{array}{l}\text { Difficult } \\
\text { Easy } \\
\text { Easy } \\
\text { Easy } \\
\text { Easy } \\
\text { Easy } \\
\text { Easy }\end{array}$ \\
\hline $\mathrm{W}$ & Small/B4 & $\begin{array}{l}\text { 1. Inventory valuation } \\
\text { 2. Breach of internal controls } \\
\text { 3. Intangibles valuation }\end{array}$ & $\begin{array}{l}\text { Discussion } \\
\text { Discussion } \\
\text { Discussion }\end{array}$ & $\begin{array}{l}\text { Measurement } \\
\text { Corp. gov. } \\
\text { Recog'n/Meas't }\end{array}$ & $\begin{array}{l}\text { Judgement } \\
\text { n/a } \\
\text { Compliance/judgement }\end{array}$ & $\begin{array}{l}\text { Acceptable } \\
\text { Not best } \\
\text { practice } \\
\text { Compliant }\end{array}$ & $\begin{array}{l}\text { Easy } \\
\text { Easy } \\
\text { Easy }\end{array}$ \\
\hline $\mathrm{R}$ & Large/B4 & $\begin{array}{l}\text { 1. Complex transaction } \\
\text { 2. Disclosures re potential } \\
\text { future losses } \\
\text { 3. Business Review }\end{array}$ & $\begin{array}{l}\text { Negotiation } \\
\text { Negotiation } \\
\text { Discussion }\end{array}$ & $\begin{array}{l}\text { Recog'n/Meas't } \\
\text { Recog'n/Meas't/ } \\
\text { Disc. } \\
\text { Disclosure }\end{array}$ & $\begin{array}{l}\text { Judgement } \\
\text { Judgement } \\
\text { Judgement }\end{array}$ & $\begin{array}{l}\text { Acceptable } \\
\text { Acceptable } \\
\text { Acceptable }\end{array}$ & $\begin{array}{l}\text { Difficult } \\
\text { Difficult } \\
\text { Easy }\end{array}$ \\
\hline $\mathrm{O}$ & $\begin{array}{l}\text { Small/not } \\
\text { disclosed }\end{array}$ & $\begin{array}{l}\text { 1. Identification of } \\
\quad \text { intangibles on acq'n } \\
\text { 2. Share-based payments } \\
\text { 3. Business Review } \\
\text { 4. Segmental reporting }\end{array}$ & $\begin{array}{l}\text { Negotiation } \\
\text { Discussion } \\
\text { Discussion } \\
\text { Discussion }\end{array}$ & $\begin{array}{l}\text { Recog'n/Meas't } \\
\text { Recog'n/Meas't } \\
\text { Disclosure } \\
\text { Disclosure }\end{array}$ & $\begin{array}{l}\text { Compliance/judgement } \\
\text { Judgement } \\
\text { Judgement } \\
\text { Judgement }\end{array}$ & $\begin{array}{l}\text { Compliant } \\
\text { Acceptable } \\
\text { Acceptable } \\
\text { Acceptable }\end{array}$ & $\begin{array}{l}\text { Difficult } \\
\text { Easy } \\
\text { Easy } \\
\text { Easy }\end{array}$ \\
\hline
\end{tabular}

Note to table:

1. Issue types were classified using the BFB scheme: recognition; measurement; classification; disclosure; and fundamental accounting principle. 
Figure 1: The grounded theory model of Beattie, Fearnley and Brandt (2001)

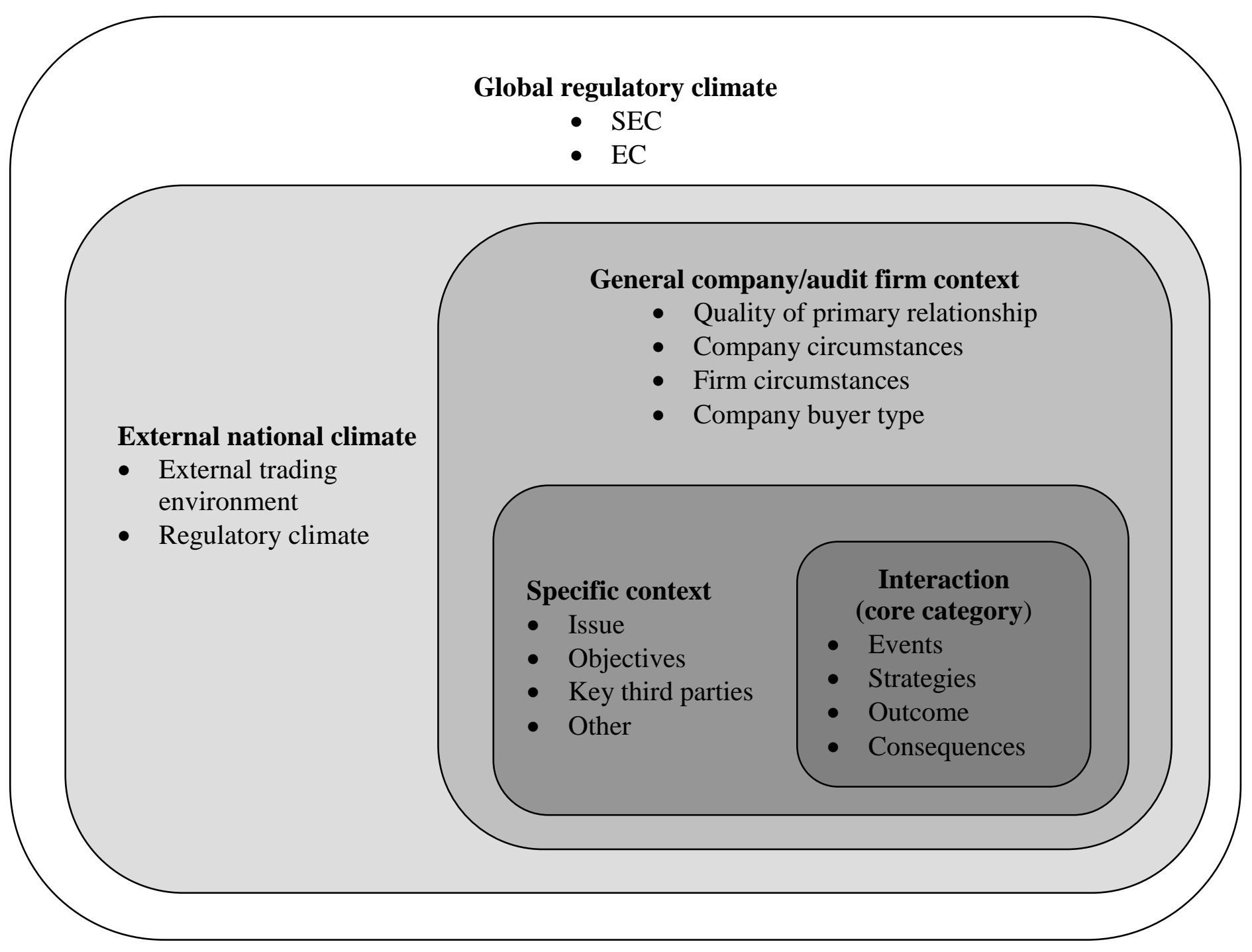

Source: Figure 12.1 in Beattie, Fearnley and Brandt, Behind Closed Doors: What Company Audit is Really About, 2001, Palgrave, reproduced with permission of Palgrave Macmillan. 
Figure 2: Principal analytical categories in the revised grounded theory of financial reporting interactions

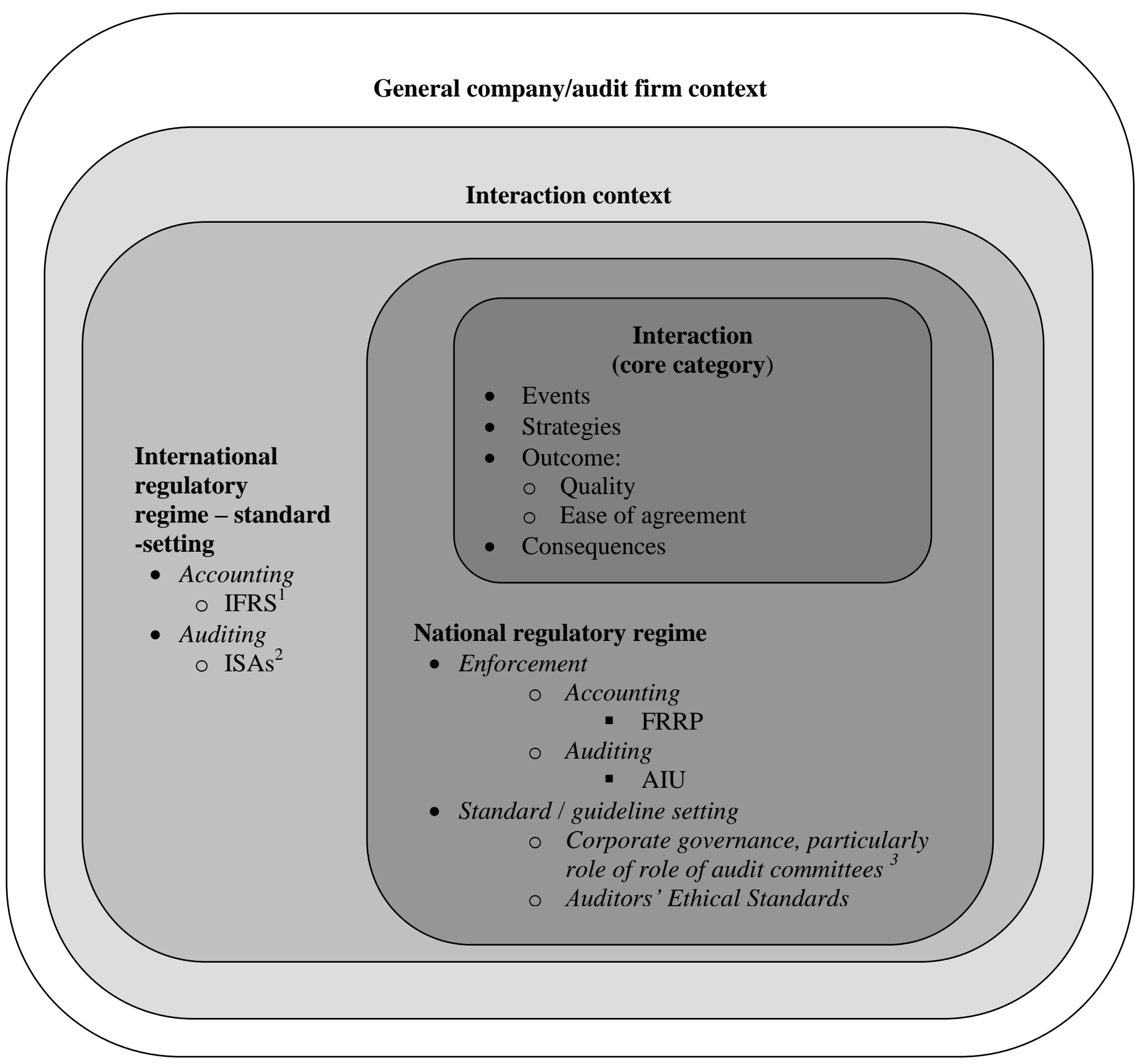

Notes to table:

1. IFRS are issued by the IASB.

2. ISAs are issued by the IAASB, with minor changes to adapt for the UK environment.

3. The UK national governance code is issued by the FRC, and compliance (on a 'comply or explain' basis) is a stock exchange listing requirement. Enforcement is therefore market-based.

Source: Figure 16.1 (p.283) in Beattie, Fearnley and Hines, Reaching Key Financial Reporting Decisions: How Directors and Auditors Interact, 2011, Wiley, reproduced with permission of Wiley. 
Figure 3: The shrinking interaction outcome domain between 1997 and 2007

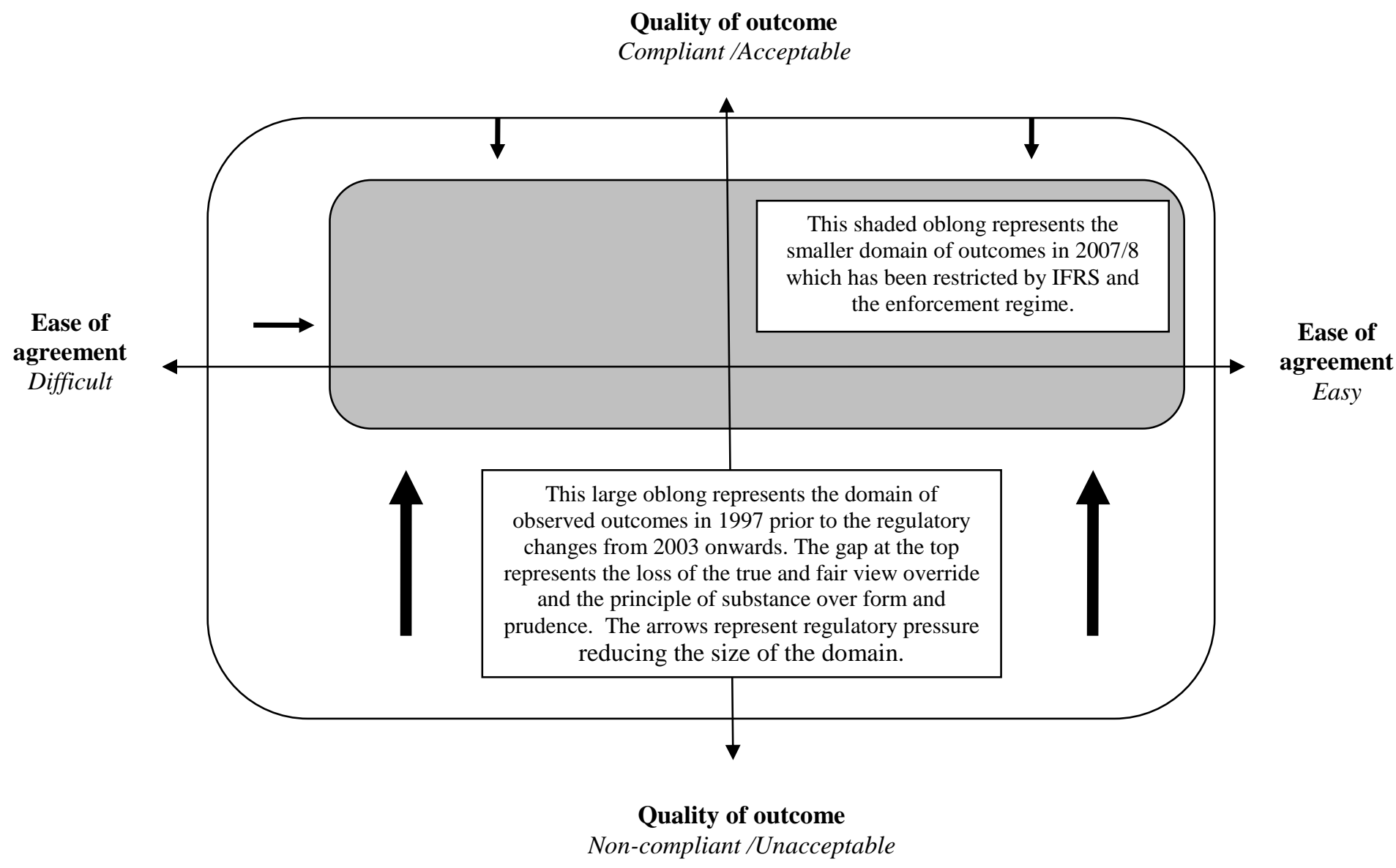

Source: Figure 16.5 (p.320) in Beattie, Fearnley and Hines, Reaching Key Financial Reporting Decisions: How Directors and Auditors Interact, 2011, Wiley, reproduced with permission of Wiley. 